\title{
Metalloid Contaminated Microhabitats and their Biodiversity at a Former Antimony Mining Site in Schlaining, Austria
}

\author{
Georg Steinhauser ${ }^{*}, 1$, , Wolfram Adlassnig ${ }^{*, 2, \S}$, Thomas Lendl ${ }^{2}$, Marianne Peroutka ${ }^{2}$, \\ Marieluise Weidinger ${ }^{2}$, Irene K. Lichtscheidl ${ }^{2}$ and Max Bichler ${ }^{1}$ \\ ${ }^{1}$ Vienna University of Technology, Atominstitut der Österreichischen Universitäten, Stadionallee 2, A-1020 Vienna, \\ Austria \\ ${ }^{2}$ University of Vienna, Cell Imaging and Ultrastructure Research Unit, Althanstraße 14, A-1090 Vienna, Austria
}

\begin{abstract}
This paper is on the biological impact of arsenic and antimony on the flora and microflora on a former Sbmining site in Schlaining (Stadtschlaining, Burgenland, Austria). Several habitats were investigated with respect to biodiversity and metalloid contamination in soil. Although the overburden of the mining activity had been remediated less than ten years ago, metalloid concentrations occurred in soil up to $1.4 \%$ As and $3.6 \% \mathrm{Sb}$, respectively, in some microhabitats, as determined by Instrumental Neutron Activation Analysis. These metalloids were embedded into a nonuniform mineralogical background. Metalloid mobility could not be explained by common models, indicating that predictions on the mobility of geogenic metalloids require additional mineralogical data. The biological effects of this contamination were variable. We observed that metalloid resistant strands of microorganisms appeared in the contaminated soil. In cultivation experiments, $\mathrm{Sb}$ was found to be more toxic than As. Sulphur oxidising strand were more resistant than organotrophic ones and grew even better on cultivation media spiked with $10 \mathrm{ppm}$ As than on the unspiked control. The flora was only partially influenced: the lowest biodiversity was found in metalloid richest soils, but moderate contamination resulted in enhanced species numbers. Only in one case, where the pH-buffering capacity of the soil was exceeded by consumption of the entire carbonate, no embryophytes occurred. This was probably due to extreme pH conditions as well as to metalloid concentrations. Our data support the hypothesis that higher plants are rather affected by extreme soil conditions, which often coincide with As contaminations, than by the contamination itself. A small rivulet in this area contained $26 \mu \mathrm{g} / 1$ and thus exceeded the WHO guideline value for As in drinking water by a factor of 2.6. Indeed we observed a diminished biodiversity in this rivulet.
\end{abstract}

Keywords: Soil antimony, soil arsenic, INAA, metalloid resistance, metallophytes, mine waste.

\section{INTRODUCTION}

\subsection{The Antiomony Mining Site at Schlaining}

Antimony ( $\mathrm{Sb})$ is a metalloid with various technological applications such as the production of flame-retardants and lead-acid batteries, as well as applications in the transportation, chemical, ceramics, and glass industries. In terms of its chemical properties, antimony is related to arsenic (As), its neighbour in the periodic table. Therefore both elements often occur simultaneously and geochemically often react in a similar way. From the environmental point of view, investigations on antimony are increasing because it has been identified as an important global pollutant [1].

In the mine in Schlaining (Stadtschlaining, Burgenland, Austria), antimony has been mined for more than 200 years. During that time, Austria was one of the main antimony producing countries worldwide due to the productivity of this

*Address correspondence to these authors at the (GS) Vienna University of Technology, Atominstitut der Österreichischen Universitäten, Stadionallee 2, A-1020 Vienna, Austria; E-mail: georg.steinhauser@ati.ac.at and (WA) University of Vienna, Cell Imaging and Ultrastructure Research Unit, Althanstraße 14, A-1090 Vienna, Austria;

E-mail: wolfram.adlassnig@univie.ac.at

${ }^{\S}$ Wolfram Adlassnig and Georg Steinhauser contributed equally to this work. mine. In the late $1990 \mathrm{~s}$, the ore has been depleted and consequently, the mine had to be abandoned in 1999. For more information on socioeconomic aspects of antimony mining in Stadtschlaining, compare Halisch [2].

The main antimony-bearing mineral mined in Schlaining was stibnite (antimonite, $\mathrm{Sb}_{2} \mathrm{~S}_{3}$ ). In petrological investigations, however, also arsenopyrite $(\mathrm{FeAsS})$ and pyrite $\left(\mathrm{FeS}_{2}\right)$ were found [3]. Some other ore minerals can be found to a minor extent, including chalcopyrite, cinnabar or sphalerite. The occurrence of the oxides of these ores has been reported in literature as well [4]. The geological setting of the mine has been classified into four lithological categories [5]: (1) $\mathrm{Sb}$-mineralised limestone and calcareous slates; (2) Sb-orefree limestone and mylonites; (3) Sb-ore-free calcareous phyllites and calcareous slates; (4) limestone. The origin of the $\mathrm{Sb}$ ore is not yet entirely clarified, but probably due to the deposition of hydrothermal, metalloid bearing solutions $[4,6]$. In the course of mining activity, substantial amounts of the waste rock have been deposited in the vicinity of the mine. These waste sites were remediated in the early $2000 \mathrm{~s}$ [7] (see section 2.1).

Cerny [5] provides chemical analyses of the rocks forming the geological setting in Schlaining: the Sb-ore bearing calcareous slates and limestone contain in average $4.4 \%$ per weight $\mathrm{Sb}, 6.1 \% \mathrm{Fe}$, and $3000 \mathrm{mg} \cdot \mathrm{kg}^{-1} \mathrm{As}$ (up to maximum 
values of $1.2 \% \mathrm{As})$. Sb-ore free limestone and mylonites contain $56 \mathrm{mg} \cdot \mathrm{kg}^{-1} \mathrm{Sb}, 185 \mathrm{mg} \cdot \mathrm{kg}^{-1} \mathrm{As}$ and $2.0 \% \mathrm{Fe}$; Sb-orefree calcareous phyllites and calcareous slates contain 35 $\mathrm{mg} \cdot \mathrm{kg}^{-1} \mathrm{Sb}, 42 \mathrm{mg} \cdot \mathrm{kg}^{-1}$ As and $1.7 \% \mathrm{Fe}$; limestone from the bedrock in this site contain $107 \mathrm{mg} \cdot \mathrm{kg}^{-1} \mathrm{Sb}, 60 \mathrm{mg} \cdot \mathrm{kg}^{-1} \mathrm{As}$ and $0.8 \% \mathrm{Fe}$.

\subsection{Toxicological Aspects of the Metalloids Arsenic and Antimony}

To humans, antimony species are almost as poisonous as the respective arsenic compounds, when injected. When ingested, however, antimony is not taken up by the human gastrointestinal tract as efficiently as arsenic. This is also reflected by the guideline values of the WHO for potable water, which are $10 \mu \mathrm{g} \cdot 1^{-1}$ for As and $50 \mu \mathrm{g} \cdot 1^{-1}$ for $\mathrm{Sb}$ (provisional guideline value). According to the WHO, the term "provisional guideline value" is used for constituents for which there is some evidence of a potential hazard but where the available information on health effects is limited [8]. Indeed, many aspects of the toxicology, the metabolism, the bioinorganic chemistry and the geochemical cycle of antimony are not well understood yet $[1,9]$. Many As compounds are known to cause cancer, including the As species occuring in contaminated drinking water. The WHO guideline value for potable water mentioned above, reflects an excess skin cancer risk of $6 \cdot 10^{-4}$.

\subsection{Aims of the Study}

The former mining site at Schlaining was investigated with respect to metalloid contamination and its biological effects. In particular, the following topics were studied:

- The efficiency of the renaturation measures at Schlaining as well as occurrence and bioavailability of ore-derived As and $\mathrm{Sb}$ in several sites in the vicinity of the mine.

- $\quad$ Effects of $\mathrm{As}$ and $\mathrm{Sb}$ on growth and diversity of higher plants and soil microorganisms at the studied contaminated habitats as well as the resistance of microorganisms against toxic metalloids and their participation in the oxidation (and thus mobilisation) of sulphidic ores.

- Soil properties of selected sites in this area with respect to factors such as inorganic nutrients, metalloid concentrations, humus content, $\mathrm{pH}$, clay content, mineralogical and petrological composition, and its consequences to metalloid mobility (The term "mobile" is defined as the water extractable percentage which is readily available to all organisms [10].). In general, heavy metal contaminated habitats are also affected by acidic soils [11].

- $\quad$ Some fundamental aspects of the role of streaming waters in the leaching of $\mathrm{As}$ and $\mathrm{Sb}$ from the spoil heaps of the former mine.

\section{MATERIALS AND METHODOLOGY}

\subsection{Sampling Sites}

A large number of sites was tested for $\mathrm{As}$ and $\mathrm{Sb}$ throughout the former mining area. Of these, four contaminated sites were selected for closer investigation. A map showing the sampling sites in the vicinity of Stadtschlaining (Burgenland/Austria) is shown in Fig. (1).

- A: Spoil heap, exposed to the west, located at $47^{\circ} 20^{\prime}$ $28,1^{\prime \prime} \mathrm{N} ; 16^{\circ} 16^{\prime} 48,9^{\prime \prime} \mathrm{E} ; 370 \mathrm{~m}$ a.s.1. In the course of remediation of the mining site, the mine's overburden was covered ("renaturated") with unpolluted soil in the early 2000s. The recent vegetation is a meadow with sporadic trees. At some areas, bold patches are found and the vegetation is partly chlorotic. Here, three microhabitats were sampled, two (A1 and A2) with a vegetation coverage of almost $100 \%$, one (A3) including sporadic bold patches.

- B: On the same spoil heap, close to Site A. Here, the coverage of unpolluted soil was removed in the course of the construction of a street. The mine waste is open now, forming a steep slope exposed to the west. The site is shadowed by trees growing nearby, but only sparsely covered by plants (B1).

- $\quad$ C: Wild boars' muddy wallow in a forest, located at $47^{\circ} 20^{\prime} 52,3^{\prime \prime} \mathrm{N} ; 16^{\circ} 16^{\prime} 21,3^{\prime \prime} \mathrm{E} ; 326 \mathrm{~m}$ a.s.1. This side of the valley had been the dumpsite of the mine's overburden until around the beginning of the $20^{\text {th }}$ century [7]. The wallow is filled with grey mud without any vegetation and obviously used by wild boars. The surrounding forest is dominated by Picea abies. The understorey is sparse. Both the mud of the wallow (C1) and the soil of the surrounding forest (C2) were sampled.

- D: Small rivulet, surrounded by a meadow, both shadowed by trees, located at $47^{\circ} 20^{\prime} 59,9^{\prime \prime} \mathrm{N} ; 16^{\circ}$ 16 ' 00,5 " E; $330 \mathrm{~m}$ a.s.1 at the hamlet of Sauerbrunn. We sampled both the rivulet (D1; sediment and water) and the soil of the meadow (D2).

Plants were collected in two series, one in the beginning of May and the other one in the middle of June 2008, in order to consider seasonal changes of vegetation. The sampled sites were chosen after a geological introduction and explanation by Dr. Josef Hofer and after a first botanical inspection, looking for typical representatives of heavy metal resistant plants. The sizes of the sites varied from large meadows to small outcrops next to a street. Accordingly, the size of the sampled areas varied considerably and depended on the area covered by a uniform vegetation. In any case, the largest-possible area has been attempted to be sampled representatively. In both sampling events, the same areas were sampled. We focused on vascular plants and mosses. Lichens were absent at all sites. Data on fungi and soil algae will be topic of later publications.

\subsection{Soil Chemistry}

Soil samples were taken from a depth of 0 to $20 \mathrm{~cm}$, corresponding to the depth of root penetration in the soil. Samples were kept a $4{ }^{\circ} \mathrm{C}$ until analysis. For analysis, fresh soil was sieved and the $<2 \mathrm{~mm}$ fraction was used in order to separate plants, roots and large rocks from the soil ${ }^{1}$. Dry

\footnotetext{
${ }^{1}$ In $\mathrm{C} 1$ and $\mathrm{D} 2$, the high stability of soil aggregates made it impossible to distinguish between the $<4 \mathrm{~mm}$ and the $<2 \mathrm{~mm}$ fraction.
} 


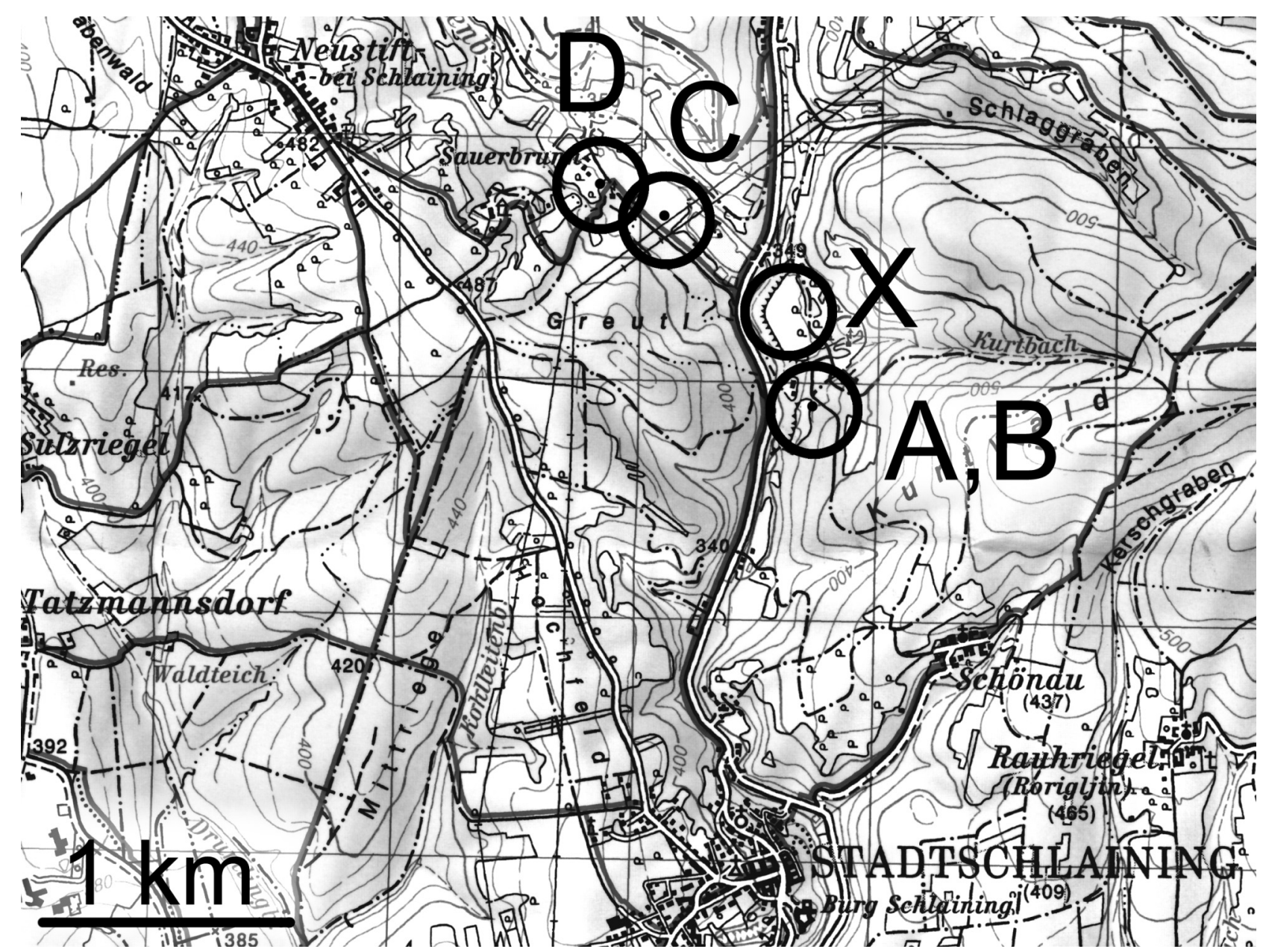

Fig. (1). Sampling sites A - D near the city of Schlaining. X indicates the former mining site (Based on [80]).

weight content was determined by drying samples of fine soil at $70^{\circ} \mathrm{C}$ until constant weight.

Actual soil $\mathrm{pH}$ was determined using a Voltcraft $\mathrm{PH}-$ 100 ATC electrode in a $25 \%$ pure water extract; for potential $\mathrm{pH}$, extracts with $0.01 \mathrm{M} \mathrm{CaCl}_{2}$ and $1 \mathrm{M} \mathrm{KCl}$ were used.

Phosphate was extracted overnight using $200 \mathrm{ml} 0.5 \mathrm{M}$ $\mathrm{NaHCO}_{3}(\mathrm{pH} 8.5)$ per $10 \mathrm{~g}$ soil according to $[12,13]$. Dissolved phosphate was determined photometrically using Merck 1.14543.0001.

Sulphate, ammonium and nitrate were extracted from 75 g dry soil overnight using $300 \mathrm{ml}$ of a $0.0125 \mathrm{M} \mathrm{CaCl}_{2}$ solution $[14,15]$. Sulphate was quantified by densitometry using Merck 1.14548.0001, both ammonium (Merck 1.14739 .0001 ) and nitrate (Merck 1.14542.0001) by photometry. Iron was extracted overnight using $100 \mathrm{ml} 0.1 \mathrm{M} \mathrm{Na}_{2} \mathrm{~S}_{2} \mathrm{O}_{4}+$ $0.57 \mathrm{M} \mathrm{Na}_{3}$-citrate [16,17] and analysed by Instrumental Neutron Activation Analysis (INAA, see section 2.5). Sulphide, total carbon, hydrogen, and nitrogen content of the soil samples were determined using CHNS elemental analysis (EA 1108 CHNS-O by Carlo Erba/Thermo-Quest), after soluble sulphate removal by washing three times with an excess of distilled water with the help of an ultrasonic bath. It can be assumed that the majority of sulphate is present in the form of passably soluble salts (such as gypsum). After this washing procedure, the samples were well-ground and dried until constant weight at $70{ }^{\circ} \mathrm{C}$.
Carbonates (as calcium carbonate) were quantified by decalcification of the samples by aqueous $\mathrm{HCl}$ and subsequent gravimetric determination. Clay content was determined by sedimentation according to Öhlinger [18]. Humus content was calculated from total $\mathrm{C}$ [19]. Humus quantification by wet oxidation [20] proved to be inapplicable since interferences with easily oxidisable sulphides were observed. Instead, the humus content was estimated from percentages of $\mathrm{C}_{\text {organic }}=\mathrm{C}_{\text {total }}-\mathrm{C}_{\text {inorganic }}$ (based on the results of the elemental analysis and carbonate analysis) using Eq. (1) [19].

Humus $(\%)=\mathrm{C}_{\text {organic }} \cdot 1.72$

Coarse particles of the bedrock were gained by sieving. Their carbonate content was tested using aqueous $\mathrm{HCl}$.

In selected samples, microscopic soil minerals were studied by X-Ray Microanalysis. Fine soil was dried at $70^{\circ} \mathrm{C}$, aggregates were broken up in a mortar. Fine particles were fixed on carbon tape and imaged at $30 \mathrm{kV}$ in a Philips LX 20; X-Ray Microanalysis was used for qualitative or semiquantitative element analysis.

\subsection{Water Chemistry}

Water from the rivulet in D2 was characterised by determination of $\mathrm{pH}$ (Voltcraft PH-100ATC), conductivity (Voltcraft WA-100ATC), carbonate hardness (Aquamerck 1.08048.0001), total hardness (Aquamerck 1.08033.0001), ammonium (Aquamerck 1.08024.0001), nitrite (Aquamerck 
1.08025.0001) nitrate (Aquamerck 1.11170.0001), phosphate (Aquamerck 1.14661.0001) and oxygen content (Aquamerck 1.11152.0001). Oxygen saturation was calculated after Oehme and Schuler [21]. Metalloid (As and $\mathrm{Sb}$ ) content was determined using INAA (see Section 2.5).

\subsection{Microbiology}

Two complementary techniques were used to evaluate the microbial diversity on the study sites in Schlaining: (1) Counting of cultivable microbes on selected media spiked with $\mathrm{Sb}$ and $\mathrm{As}$ and (2) determination of total microbe number in situ after fluorescent staining.

(1) For cultivation experiments, fresh soil with a dry weight of $10 \mathrm{~g}$ was extracted in $90 \mathrm{ml}$ sterile phosphate buffer $(0.2 \%, \mathrm{pH} 7.0)$ for 45 minutes at 150 rpm [22]. After 20 minutes for sedimentation of coarse particles, the extracts were diluted $1: 200$ to 1 : 160,000 and $100 \mu 1$ of each were inoculated on the following media: 1) Plate Count Medium (Merck Plate-Count-Agar 1.05463.0500) for the unspecific quantification of cultivable bacteria, 2) Kimmig Medium for the isolation of fungi [23], 3) a selective medium for sulphide oxidising bacteria (SOB; [24]). Furthermore, we tested a selective medium for actinobacteria as described by Papageorgiou [25], which proved to be too unspecific for our purposes. The plates were incubated for seven days at room temperature. Spiking was performed by adding 10 and $100 \mathrm{ppm}$ As and Sb to the media. Antimony was applied as tartar emetic (potassium antimony(III) oxide tartrate hemihydrate, $\mathrm{K}(\mathrm{SbO}) \mathrm{C}_{4} \mathrm{H}_{4} \mathrm{O}_{6} \cdot 0.5 \quad \mathrm{H}_{2} \mathrm{O}$; Merck, Darmstadt, puriss.), whereas arsenic was used as disodium hydrogenarsenate $\left(\mathrm{Na}_{2} \mathrm{HAsO}_{4} \cdot 7 \mathrm{H}_{2} \mathrm{O}\right.$; Riedel de Haën, Seelze, puriss.).

(2) For the determination of the total microbe number [22], the same soil extracts were diluted $1: 1$ with sterile water. After adding a $1 \%$ agarose solution, $40 \mu \mathrm{l}$ of the solution were transferred to slides and stained with $0.0065 \%$ Acridine Orange. After washing, the stained bacteria were counted using an Olympus BX-41 epifluorescence microscope (4 parallel preparations and 20 counts per soil).

\subsection{Determination of Metalloid Content}

Quantification of metalloids and Fe was performed by Instrumental Neutron Activation Analysis (INAA). The content of arsenic and antimony was determined in the water of the rivulet at D2 as well as in the soil. In the latter case, we distinguished between the total metalloid content of the fine soil and mobile metalloids ( $10 \mathrm{~g}$ extracted with $67 \mathrm{ml}$ of pure water). Furthermore, we tested the potential of $1 \mathrm{M} \mathrm{NH}_{4} \mathrm{NO}_{3}$ to extract exchangeable metalloids (extractable metalloids).

For the quantification of metalloids, INAA offers several advantages compared to other analytical methods, i.e. no matrix dependency as well as no dependency on the oxidation state or the chemical environment of the analyte. Furthermore, INAA requires only a minimum of sample preparation (inter alia avoiding chemical dissolution of the insoluble ores), which makes it the method of choice e.g. for geological samples $[26,27]$. Both elements, arsenic and antimony, can be determined with extreme sensitivity. The geological material was carefully dried at $70{ }^{\circ} \mathrm{C}$ until constant weight, homogenised in an agate mortar, weighed into polyethylene vials, sealed and irradiated in the TRIGA Mark II reactor at the Atominstitut for 4 minutes using the pneumatic sample transfer system. The neutron flux density in this position is approximately $3 \cdot 10^{12} \mathrm{~cm}^{-2} \cdot \mathrm{s}^{-1}$. For quantification, the certified standard reference materials (NIST SRM 1633b Coal Fly Ash and NIST SRM 2702 Inorganics in Marine Sediments) were used.

After a cooling time of 24 hours, the vials were decontaminated and a $\gamma$-spectrum was measured to obtain the activities of the relatively short-lived activation products ${ }^{76} \mathrm{As}$ and ${ }^{122} \mathrm{Sb}$ (see Table 1). The measuring time was $1800 \mathrm{~s}$. All samples were measured in a fixed position at a distance of 8 $\mathrm{cm}$ beside the detector. The $\gamma$-spectrometry was performed with a $222 \mathrm{~cm}^{3}$ HPGe-detector $(1.78 \mathrm{keV}$ resolution at the $1332 \mathrm{keV}{ }^{60} \mathrm{Co}$ peak; $48.2 \%$ relative efficiency), connected to a PC-based multi-channel analyzer with a preloaded filter and a Loss-Free Counting system.

For quality control, solutions of $\mathrm{Na}_{2} \mathrm{HAsO}_{4} \cdot 7 \mathrm{H}_{2} \mathrm{O}$ and $\mathrm{K}(\mathrm{SbO}) \mathrm{C}_{4} \mathrm{H}_{4} \mathrm{O}_{6} \cdot 0.5 \mathrm{H}_{2} \mathrm{O}$ with each $100 \mathrm{mg} \cdot \mathrm{l}^{-1} \mathrm{As}$ and $\mathrm{Sb}$, respectively, were analysed in each analytical cycle. For the quantification of ${ }^{76} \mathrm{As}$ and ${ }^{122} \mathrm{Sb}$, the bromine content of the sample is a crucial factor: The main photo peaks of the three

Table 1. Basic Nuclear Data that are Important for the INAA in this Study

\begin{tabular}{|c|c|c|c|c|c|c|}
\hline Element & $\begin{array}{c}\text { Nuclide Capable for Neu- } \\
\text { tron Capture (Natural } \\
\text { Abundance) }\end{array}$ & $\begin{array}{l}\text { Cross Section for Ther- } \\
\text { mal Neutron Capture, } \\
(\mathrm{n}, \gamma) \text {-Reaction }\end{array}$ & $\begin{array}{c}\text { Activation } \\
\text { Product }\end{array}$ & $\begin{array}{c}\text { Detectable After } \\
\text { Short or Long-Term } \\
\text { Activation }\end{array}$ & Half-Life & $\begin{array}{c}\gamma \text {-Photon Energy } \\
{[\mathrm{keV}] \text { (Branching }} \\
\text { Ratio) }\end{array}$ \\
\hline Antimony & ${ }^{121} \mathrm{Sb}(57.21 \%)$ & $5.9 \mathrm{~b}$ & ${ }^{122} \mathrm{Sb}$ & short-term (1-4 min) & $2.7238 \mathrm{~d}$ & $564.24(70.67 \%)$ \\
\hline Antimony & ${ }^{123} \mathrm{Sb}(42.79 \%)$ & $4.06 \mathrm{~b}$ & ${ }^{124} \mathrm{Sb}$ & long-term $(>8 \mathrm{~h})$ & $60.11 \mathrm{~d}$ & $1690.975(47.79 \%)$ \\
\hline Arsenic & ${ }^{75} \mathrm{As}(100 \%)$ & $4.3 \mathrm{~b}$ & ${ }^{76} \mathrm{As}$ & short-term (1-4 min) & $1.0942 \mathrm{~d}$ & $\begin{array}{l}559.10(45.0 \%) \\
563.23(1.20 \%)\end{array}$ \\
\hline Bromine & ${ }^{81} \mathrm{Br}(45.31 \%)$ & $2.64 \mathrm{~b}$ & ${ }^{82} \mathrm{Br}$ & short- and long-term & $35.282 \mathrm{~h}$ & $\begin{array}{l}776.517(83.4 \%) \\
554.348(71.1 \%) \\
619.106(43.5 \%)\end{array}$ \\
\hline Iron & ${ }^{58} \mathrm{Fe}(0.282 \%)$ & $1.3 \mathrm{~b}$ & ${ }^{59} \mathrm{Fe}$ & long term $(>8 \mathrm{~h})$ & $44.495 \mathrm{~d}$ & $1099.245(56.5 \%)$ \\
\hline
\end{tabular}

Data taken from [79].

$1 \mathrm{~b}$ (barn) $=10^{-24} \mathrm{~cm}^{2}$; this value represents the total cross section (including neutron capture yielding short-lived metastable nuclear levels). 


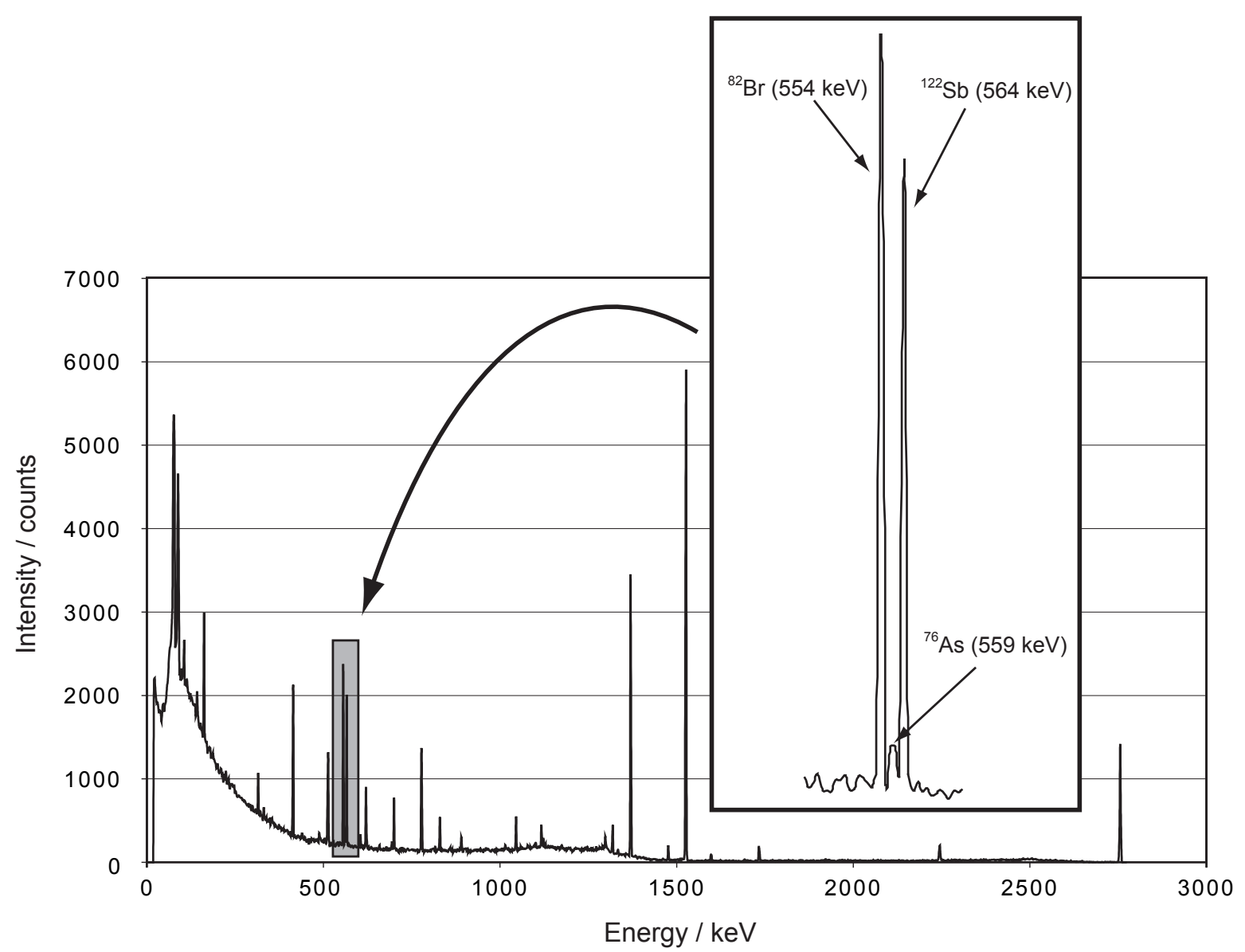

Fig. (2). Gamma-spectrum of a $\mathrm{Br}$, As, and Sb-containing water sample from the rivulet (location $\mathrm{D}$ ). The spectrum shows the potential interference of ${ }^{82} \mathrm{Br}$ with the main photopeaks of ${ }^{76} \mathrm{As}$ and ${ }^{122} \mathrm{Sb}$ in bromide-rich matrices.

activation products are within a very small energy range in the $\gamma$-spectrum (see Table 1). Thus a high content of bromine in the sample can cause the overlap of the $554 \mathrm{keV}$ peak with the other two photopeaks and thwart a reliable peak evaluation. In our case, the $\mathrm{Br}$ content was low enough in every case to resolve these three peaks and provide a flawless analysis (Fig. 2). Also, the $563 \mathrm{keV}$ photo peak of ${ }^{76} \mathrm{As}$ contributes only marginally to the $564 \mathrm{keV}^{122} \mathrm{Sb}$-peak due to the small branching ratio (the percentage of disintegrations with the emission of a $\gamma$-photon) of this $\gamma$-photon (compare Table 1). However, this overlap has been accounted for by evaluating a pure arsenic standard.

For quantification of the iron content in soil extracts, $1 \mathrm{ml}$ of the extract was pipetted into Suprasil ${ }^{\mathrm{TM}}$ quartz glass vials and carefully evaporated at $80{ }^{\circ} \mathrm{C}$. After complete evaporation, the quartz vials were sealed and irradiated together with standard samples in an irradiation tube (neutron flux density approximately $2 \cdot 10^{12} \mathrm{~cm}^{-2} \cdot \mathrm{s}^{-1}$ ) of the reactor for approximately 35 hours. Since ${ }^{59} \mathrm{Fe}$ is a long-lived activation product, the $\gamma$-measurement was performed two weeks after irradiation, i. e. after complete cooling of the remarkable ${ }^{24} \mathrm{Na}$ background $\left(\mathrm{T}_{1 / 2}=15.0 \mathrm{~h}\right)$, which was a consequence of the utilisation of sodium dithionite and citrate as a reducing and coordinating agent in the course of extraction. After decontamination of the vials, they were packed into PE vials fitting the automatic sample changer device of the Atominstitut in Vienna and measured on the same $\gamma$-detection sys- tem as described before at a distance of $4 \mathrm{~cm}$ to the detector. Standard materials for iron were ferric-ammonium sulphate $\left(\mathrm{NH}_{4} \mathrm{Fe}\left(\mathrm{SO}_{4}\right)_{2} \cdot 12 \mathrm{H}_{2} \mathrm{O}\right.$; Merck, Darmstadt, p.a.) and iron powder (Merck, Darmstadt, p.a.). The analytical error of the INAA in this work is $\leq 5 \%$ rel. for $\mathrm{Sb}$ and $<10 \%$ rel. for As and Fe.

\subsection{Statistics}

SPSS 16.0 was used for statistical analysis. The Kolmogorov-Smirnov test gave evidence that none of our data were normally distributed. Thus, the Mann-Whitney-U-test was used to test for differences. The Spearman test was used to test for correlations of soil parameters, where no causeeffect relations were evident. Biodiversity of embryophytes as well as the number of bacteria were regarded as effects of the soil composition. Therefore, linear regression was used in those cases.

\section{RESULTS}

\subsection{Soil}

The soils of the various sampling sites proved to be very different. The majority of samples, however, showed to be moderately rich in nutrients, rich in carbonates and with a neutral $\mathrm{pH}$. A survey of chemical soil parameters is given in Table 2. With the exception of $\mathrm{C} 1$, all soils were well aer- 
Table 2. Soil Composition at the Test Sites

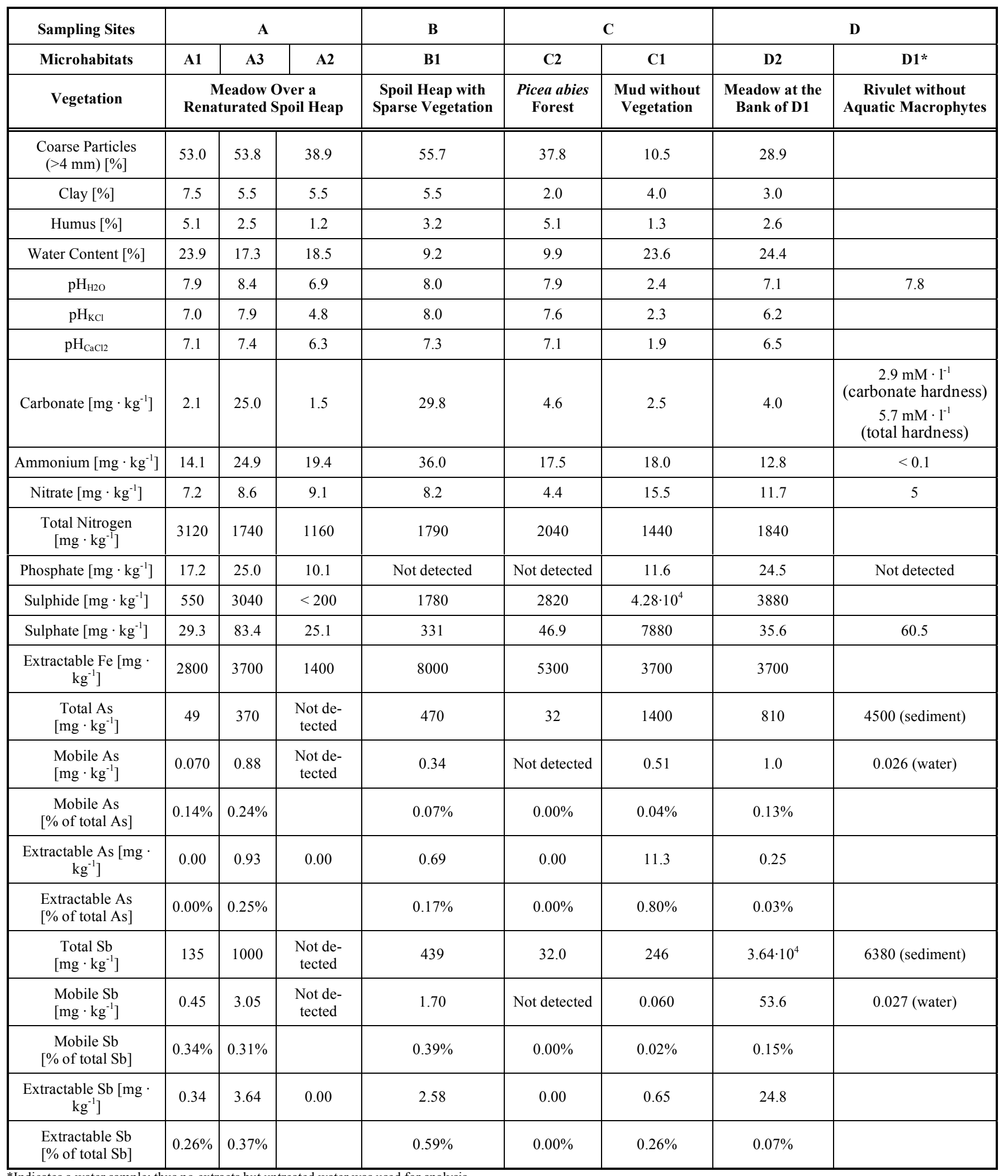

*Indicates a water sample; thus no extracts but untreated water was used for analysis.

ated. No black sulphide layers were found that might indicate anaerobic conditions [28].

At site A, three samples were taken. In A1, the uppermost $10 \mathrm{~cm}$ were densely penetrated by roots. Below, large rocks were found; the majority of these was rich in carbonates (calcareous slates), only a minor amount was serpentinite. The fine soil was moderately calcareous and exhibited a neutral $\mathrm{pH}$. Contamination with metalloids was low, but well above the detection limit. At A3, only sparse roots were 
found in the uppermost $6 \mathrm{~cm}$. The rocky mineral below primarily consisted of calcareous phyllite (graphitic slate) with minor amounts of green slate with sulphide inclusions (Fig. 3). The soil at this site was calcareous and slightly alkaline. The contamination with metalloids was about seven times higher than in A1. In A2, the rooted soil layer was deeper than $20 \mathrm{~cm}$. Rocks (green slate with quartz inclusions; phyllite) were evenly distributed through the soil; none of them was calcareous. Soil $\mathrm{pH}$ was slightly acidic. No detectable amounts of metalloids were found in the fine soil fraction.

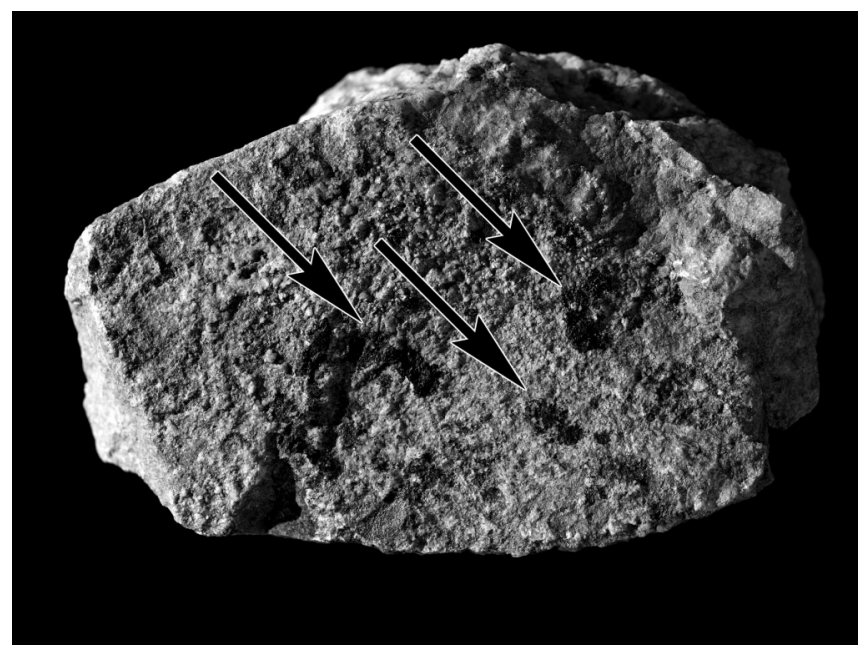

Fig. (3). Green slate with several ore inclusions (arrow) diameter $\sim 8 \mathrm{~cm}$.

At site B, the soil was rich in large particles and exhibited no distinct soil layers. All rocks were calcareous phyllites (graphitic slates); accordingly, soil $\mathrm{pH}$ was slightly alkaline. The fine soil contained even more As, but less Sb than A3. Furthermore, large amounts of sulphate were found.

At site $\mathrm{C}$, mud in a wallow (C1) and forest soil (C2) were distinguished. At $\mathrm{C} 2$, soil was covered by a thin layer of spruce needles and duff. Below, an unstratified soil was found. All rocky stones were calcareous phyllites (graphitic slates); soil $\mathrm{pH}$ was $>7$. Only very small amounts of As and $\mathrm{Sb}$ were detected. $\mathrm{C} 1$ exhibited completely different properties than all other samples: The mud was wet; no roots and no soil layers were detected. Spruce needles, fir cones and other organic particles were obviously conserved for a longer time period. The soil was extremely acidic ( $\mathrm{pH} 2.38$ in water, 1.88 in $\mathrm{CaCl}_{2}$ ). Accordingly, little carbonate was found in the fine soil nor in the sparse rock particles. The mud contained $7.9 \%$ sulphate and even $4 \%$ sulphide. In the X-Ray Microanalysis, numerous crystals of gypsum were found (Fig. 4). Furthermore, 1.4\% As, but comparatively little $\mathrm{Sb}$ were found.

Site D consisted of two microhabitats as well, a rivulet and a meadow. The bedrock material of rivulet D1 was covered by a flocculent red iron ore mineral, probably goethite (Fig. 5). In the rivulet's water, the maximum permissible value in drinking water (World Health Organization, WHO [8]) for As $\left(10 \mu \mathrm{g} \cdot \mathrm{l}^{-1}\right)$ was clearly exceeded. The value for $\mathrm{Sb}$ was in the same range but yet below the limit which is $50 \mu \mathrm{g} \cdot 1^{-1}$ in this case. The sediment, especially the iron hydroxide, contained up to $4.5 \%$ As. The sorption of As species onto iron hydroxide has been object of intense investigation (e.g. [29]). The meadow D2 along the bank is probably affected by flooding. The soil is loamy, poor in large rocks and only sparsely penetrated by roots. About half of the rocks were calcareous phyllites; the other half was serpentinite and partly anthropogenic smelting residues; soil $\mathrm{pH}$ was neutral. Furthermore, small scoria particles $(<4 \mathrm{~mm})$ were abundant. The soil was very rich in As and especially in $\mathrm{Sb}$; the percentage of mobile metalloids were relatively high as well.

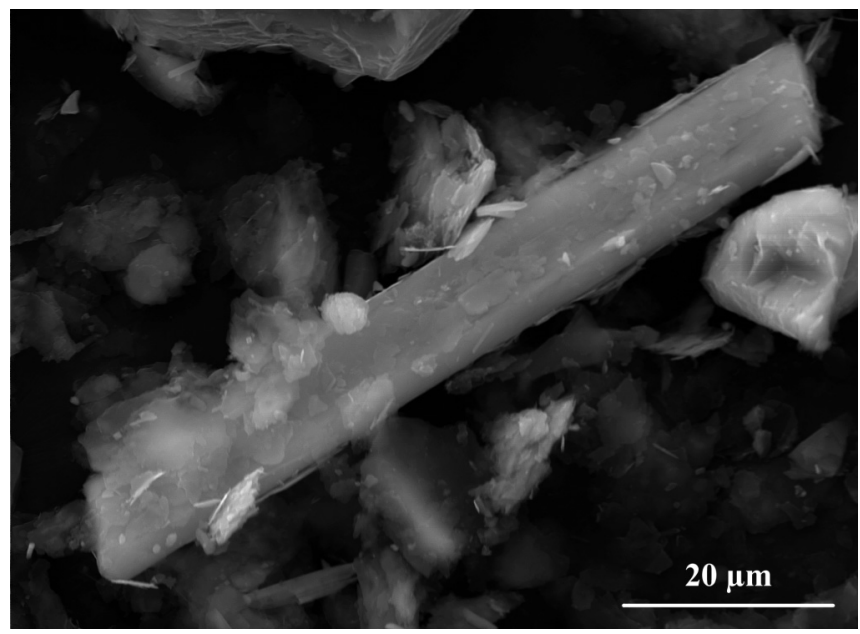

Fig. (4). Gypsum crystal from the mud of C1 (X-Ray Microanalysis).

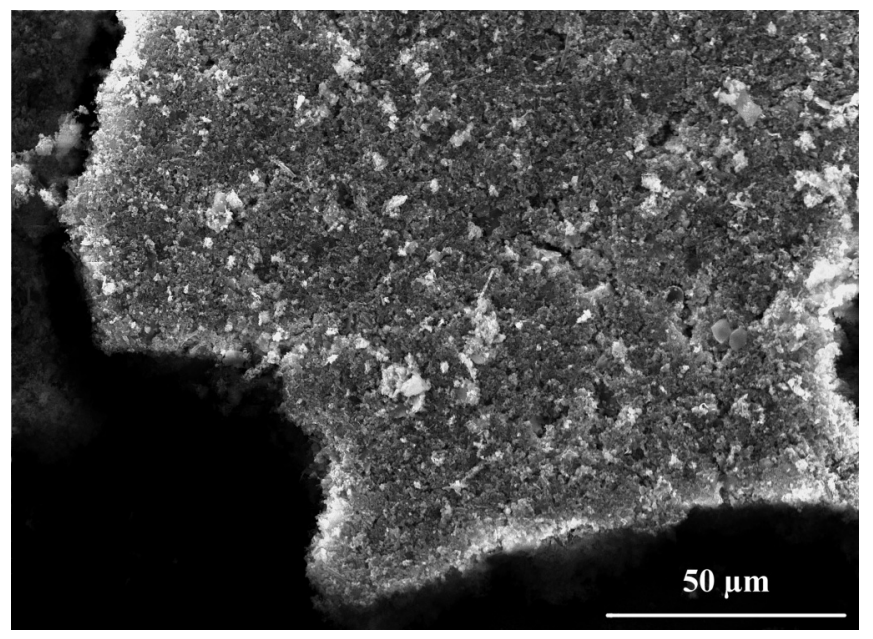

Fig. (5). Iron ore particle (goethite) from rivulet D1. This specific particle contained $0.36 \%$ adsorbed As (X-Ray Microanalysis).

At none of the sites, antimony ore particles could be found in the fine soil using X-Ray Microanalysis. Instead, quartz, alumosilicates, mica, clinopyroxene, hornblende and other microscopic mineral particles could be identified which contained up to $1 \% \mathrm{Sb}$ and $0.2 \%$ As.

\subsection{Flora}

At site A, 51 species of Embryophytes were found (Table 3). At A1 (26 species) and A2 (16 species), the vegetation was very dense and dominated by grasses and herbs. At A3 (29 species), shrubs and mosses were found as well. Vegetation density, however, was lower and spots of open soil occurred.

At site B, 15 species were found (Table 4). As this habitat was located at the edge of the forest, meadow and forest 
Table 3. Vascular Plants and Bryophytes Found at Site A

\begin{tabular}{|c|c|c|}
\hline A1 & $\mathbf{A 3}$ & A2 \\
\hline $30 \mathrm{~m}^{2}$ Sampled & $50 \mathrm{~m}^{2}$ Sampled & $50 \mathrm{~m}^{2}$ Sampled \\
\hline Achillea millefolium agg. (Asteraceae) & Acer campestre (Aceraceae) & Aegopodium podagraria (Apiaceae) \\
\hline Aegopodium podagraria (Apiaceae) & Alopecurus pratensis (Poaceae) & Arrhenaterum elatius (Poaceae) \\
\hline Arrhenaterum elatius (Poaceae) & Arrhenaterum elatius (Poaceae) & Aster lanceolata (Asteraceae) \\
\hline Aster lanceolata (Asteraceae) & Aster lanceolata (Asteraceae) & Calamogrostis epigeios (Poaceae) \\
\hline Avenula pubescens (Poaceae) & Avenula pubescens (Poaceae) & Dactylis glomerata (Poaceae) \\
\hline Carex hirta (Cyperaceae) & Barbula unguiculata (Pottiaceae) & Festuca pratensis (Poaceae) \\
\hline Cirsium sp. (Asteraceae) & Brachythecium oedipodium (Brachytheciaceae) & Galium mollugo (Rubiaceae) \\
\hline Dactylis glomerata (Poaceae) & Campanula patula (Campanulaceae) & Holcus sp. (Poaceae) \\
\hline Festuca pratensis (Poaceae) & Carpinus betulus (Betaluceae) & Knautia arvensis (Scabiosaceae) \\
\hline Hypericum perforatum (Hypericaceae) & Carex hirsuta (Cyperaceae) & Lamium album (Lamiaceae) \\
\hline Knautia arvensis (Scabiosaceae) & Clematis vitalba (Ranunculaceae) & Leucanthemum sp. (Asteraceae) \\
\hline Lathyrus pratensis (Fabaceae) & Festuca pratensis (Poaceae) & Lotus corniculatus (Fabaceae) \\
\hline Lotus corniculatus (Fabaceae) & Galium aparine (Rubiaceae) & Myosotis arvensis (Boraginaceae) \\
\hline Mentha sp. (Lamiaceae) & Galium mollugo (Rubiaceae) & Potentilla sp. (Rosaceae) \\
\hline Potentilla sp. (Rosaceae) & Knautia maxima (Scabiosaceae) & Solidago cf. canadensis (Asteraceae) \\
\hline Pulmonaria officinalis (Boraginaceae) & Lamium album (Lamiaceae) & Urtica dioica (Urticaceae) \\
\hline Ranunculus sp. (Ranunculaceae) & Lysimachia nummularia (Primulaceae) & \\
\hline Rubus sp. (Rosaceae) & Lysimachia punctata (Primulaceae) & \\
\hline Rumex crispus (Polygonaceae) & Mnium marginatum (Mniaceae) & \\
\hline Scutellaria hastifolia (Lamiaceae) & Myosotis arvensis (Boraginaceae) & \\
\hline Silene vulgaris (Caryophyllaceae) & Origanum vulgare (Lamiaceae) & \\
\hline Solidago cf. canadensis (Asteraceae) & Potentilla sp. (Rosaceae) & \\
\hline Vicia cracca (Fabaceae) & Pulmonaria officinalis (Boraginaceae) & \\
\hline Vicia grandiflora (Fabaceae) & Pyrus pyraster (Rosaceae) & \\
\hline Vicia hirsuta (Fabaceae) & Robinia pseudacacia (Fabaceae) & \\
\hline \multirow[t]{4}{*}{ Vicia sepium (Fabaceae) } & Salvia glutinosa (Lamiaceae) & \\
\hline & Solidago cf. canadensis (Asteraceae) & \\
\hline & Thlaspi sp. (Brassicaceae) & \\
\hline & Trisetum flavescens (Poaceae) & \\
\hline 26 species & 29 species & 16 species \\
\hline
\end{tabular}

species intermixed. The vegetation consisted of shrubs, young trees and herbs; mosses and grasses were missing.

Site $\mathrm{C}$ was dominated by Picea abies which were planted by man. In the forest, 24 additional species were found. Besides sparse shrubs and young trees ${ }^{2}$, we found mainly the fern Dryopteris filix-mas and abundant mosses (9 species). The wallow $\mathrm{C} 1$ was found without any vegetation. The only organisms were bacteria occasionally forming orange biofilms.

${ }^{2}$ Without Picea abies, which does not reproduce in Burgenland.
At site D, rivulet D1 proved to have similar characteristics to the wallow. No aquatic mosses, vascular plants or algae were found; however, Thiothrix-like bacteria (Fig. 6) formed filaments between particles of iron hydroxide. D2, the meadow at the bank of the rivulet, was very poor in species as well. Only six species of vascular plants were found. Two bryophytes, Pellia cf. epiphylla and Plagiomnium undulatum, covered most of the area.

Although the highest diversity of embryophytes was found in a contaminated habitat (A3), comparison of all habitats showed that total soil As content led to a significant decrease in biodiversity $\left(\mathrm{R}^{2}=0.62 ; \mathrm{P}<0.05\right)$. Mobile and extractable As or Sb had no significant effect on the biodi- 
Table 4. Embryophytes Found at the Spoil Heap B1, the Picea abies Forest C2 and the Meadow D2

\begin{tabular}{|c|c|c|}
\hline B1 & $\mathrm{C} 2$ & D2 \\
\hline $10 \mathrm{~m}^{2}$ Sampled & $15 \mathrm{~m}^{2}$ Sampled & $5 \mathrm{~m}^{2}$ Sampled \\
\hline Cardaminopsis arenosa (Brassicaceae) & Asarum europaeum (Aristolochiaceae) & Geranium sp. (Geraniaceae) \\
\hline Cornus sanguinea (Cornaceae) & Betula sp. (Betulaceae) & Hedera helix (Araliaceae) \\
\hline Corylus avellana (Betulaceae) & Brachythecium velutinum (Brachytheciaceae) & Oxalis sp. (Oxalidaceae) \\
\hline Eupatorium cannabinum (Asteraceae) & Carpinus betulus (Betulaceae) & Pellia cf. epiphylla (Pelliaceae) \\
\hline Fagus sylvatica (Fagaceae) & Cornus sanguineus (Cornaceae) & Plagiomnium undulatum (Mniaceae) \\
\hline Fragaria vesca (Rosaceae) & Dryopteris filix-mas (Dryopteridaceae) & Viola sp. (Violaceae) \\
\hline Galium aparine (Rubiaceae) & Epilobium sp. (Onagraceae) & \\
\hline Geum sp. (Rosaceae) & Eupatorium cannabinum (Asteraceae) & \\
\hline Impatiens noli-tangere (Balsaminaceae) & Eurhynchium angustirete (Brachytheciaceae) & \\
\hline Knautia maxima (Scabiosaceae) & Fragaria vesca (Rosaceae) & \\
\hline Melica nutans (Poaceae) & Galium aparine (Rubiaceae) & \\
\hline Rosa sp. (Rosaceae) & Geum sp. (Rosaceae) & \\
\hline Rubus sp. (Rosaceae) & Hypercicum perforatum (Hyperciaceae) & \\
\hline Solidago cf. canadensis (Asteraceae) & Hypnum cupressiforme (Hypnaceae) & \\
\hline \multirow[t]{11}{*}{ Tilia platyphylla (Tiliaceae) } & Impatiens noli-tangere (Balsaminaceae) & \\
\hline & Isopterygium muellerianum (Brachytheciaceae) & \\
\hline & Lophocolea heterophylla (Geocalycaeae) & \\
\hline & Picea abies (Pinaceae) & \\
\hline & Plagiochila asplenoides (Plagiochilaceae) & \\
\hline & Plagiothecium curvifolium (Plagiotheciaceae) & \\
\hline & Polytrichum formosum (Polytrichaceae) & \\
\hline & Pottia sp. (Pottiaceae) & \\
\hline & Rubus sp. (Rosaceae) & \\
\hline & Sambucus nigra (Sambucaceae) & \\
\hline & Viburnum sp. (Adoxaceae) & \\
\hline 15 species & 25 species & 6 species \\
\hline
\end{tabular}

versity. Other factors reducing the number of species included lacking soil skeleton $\left(\mathrm{R}^{2}=0.60 ; \mathrm{P}<0.05\right)$ and low soil $\mathrm{pH}$, especially $\mathrm{pH}_{\mathrm{H} 2 \mathrm{O}}\left(\mathrm{R}^{2}=0.55 ; \mathrm{P}<0.05\right)$. Due to the limited number of samples analysed, statistical interpretation in this work should be regarded as preliminary information in the first place.

\subsection{Microbiology}

The number of soil bacteria ranged between $7.3 \cdot 10^{8}$ per gram for the wallow $\mathrm{C} 1$ and $7.2 \cdot 10^{9}$ for the meadow A1. A weak negative correlation was found between the total number of bacteria and total As $\left(\mathrm{R}^{2}=0.27 ; \mathrm{P}<0.01\right)$, mobile As $\left(\mathrm{R}^{2}=0.17 ; \mathrm{P}<0.01\right)$, total $\mathrm{Sb}\left(\mathrm{R}^{2}=0.03 ; \mathrm{P}<0.05\right)$ and mobile $\mathrm{Sb}\left(\mathrm{R}^{2}=0.03 ; \mathrm{P}<0.05\right)$. Other factors were found to inhibit bacterial growth as well, including low $\mathrm{pH}_{\mathrm{CaCl} 2}\left(\mathrm{R}^{2}=\right.$ $0.15 ; \mathrm{P}<0.01)$, and even shadowing $\left(\mathrm{R}^{2}=0.55 ; \mathrm{P}<0.01\right)$. On the other hand, the number of soil bacteria was positively influenced by clay content $\left(\mathrm{R}^{2}=0.59 ; \mathrm{P}<0.01\right)$, total soil $\mathrm{N}$ $\left(\mathrm{R}^{2}=0.41 ; \mathrm{P}<0.01\right)$ or total soil $\mathrm{H}\left(\mathrm{R}^{2}=0.40 ; \mathrm{P}<0.01\right)$.

The number of cultivable units on PC medium showed no correlation with the total number of bacteria as well. Culti- vable sulphur oxidising bacteria were found in all samples except $\mathrm{C} 1$. Microbe numbers are given in Table $\mathbf{5}$.

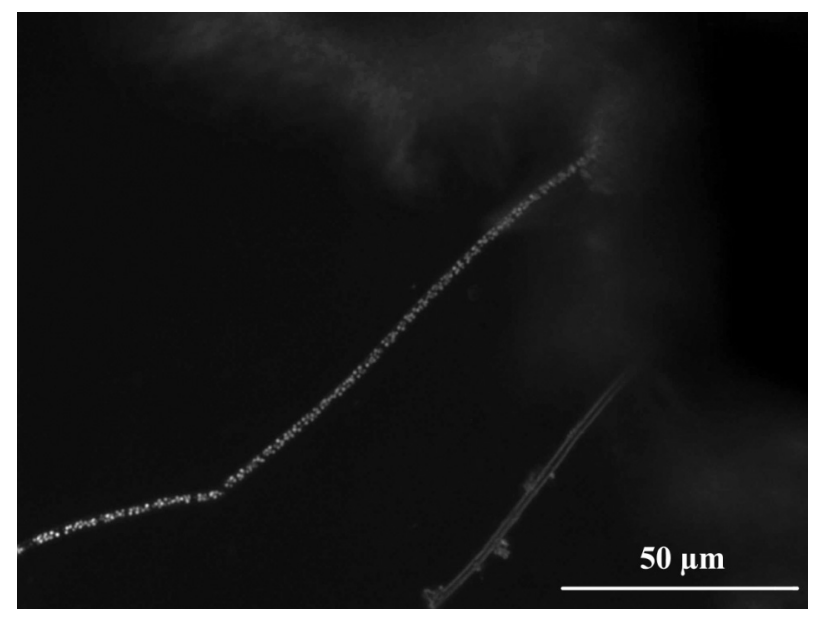

Fig. (6). Filamentous, Thiothrix nivea-like bacterium attached to an iron hydroxide particle. This organism is by far dominant in rivulet D1. Note the white sulphur globules inside the cells (dark field). 
Table 5. Microbe Numbers, as Quantified by Fluorescent Microscopy and Two Different Culture Media (Values per g)

\begin{tabular}{|c|c|c|c|c|c|c|c|c|}
\hline $\begin{array}{l}\text { Sampling } \\
\text { Site }\end{array}$ & A1 & A3 & A2 & B1 & C2 & C1 & D2 & D1 \\
\hline $\begin{array}{c}\text { Total } \\
\text { Bacteria }\end{array}$ & $7.16 \pm 1.26 \cdot 10^{9}$ & $3.54 \pm 0.82 \cdot 10^{9}$ & $3.25 \pm 0.84 \cdot 10^{9}$ & $1.49 \pm 0.18 \cdot 10^{9}$ & $1.18 \pm 0.27 \cdot 10^{9}$ & $7.25 \pm 1.3 \cdot 10^{8}$ & $1.60 \pm 0.30 \cdot 10^{9}$ & \\
\hline $\begin{array}{l}\text { Cultivable } \\
\text { Units on } \\
\text { PC medium }\end{array}$ & $3.20 \pm 7.12 \cdot 10^{8}$ & $6.54 \pm 13.8 \cdot 10^{8}$ & $2.70 \pm 7.84 \cdot 10^{8}$ & $3.53 \pm 7.84 \cdot 10^{8}$ & $4.01 \pm 4.31 \cdot 10^{8}$ & $1.95 \pm 0.01 \cdot 10^{8}$ & $5.36 \pm 11.0 \cdot 10^{8}$ & $\begin{array}{c}0.56 \\
\quad \pm \\
10.3 \cdot 10^{8}\end{array}$ \\
\hline $\begin{array}{l}\text { Cultivable } \\
\text { Units on } \\
\text { SOB medium }\end{array}$ & $1.80 \pm 2.83 \cdot 10^{5}$ & $3.06 \pm 1.41 \cdot 10^{5}$ & $3.96 \pm 6.22 \cdot 10^{5}$ & $1.28 \pm 2.01 \cdot 10^{5}$ & $5.40 \pm 8.49 \cdot 10^{4}$ & Not detected & $1.35 \pm 0.14 \cdot 10^{5}$ & $\begin{array}{c}1.80 \\
\pm \\
2.55 \cdot 10^{4}\end{array}$ \\
\hline
\end{tabular}

Bacteria cultivated on PC and SOB medium exhibited completely different reactions on As and Sb spiking of the medium: on PC medium the number of colonies decreased with $\mathrm{As}$ and $\mathrm{Sb}$ contamination; here, Sb proved to be more toxic than As. On a medium spiked with $100 \mathrm{ppm}$ As less than $9 \%$, on $100 \mathrm{ppm} \mathrm{Sb}$ less than $0.12 \%$ were able to grow, compared to the unspiked control (Figs. 7 and $\mathbf{8}$ ). The majority of sulphur oxidising bacteria, on the other hand, exhibited most abundant growth on media spiked with $10 \mathrm{ppm}$ As. Neither 100 ppm As, nor Sb-spiking led to a significant reduction in this case (Figs. 9 and 10).

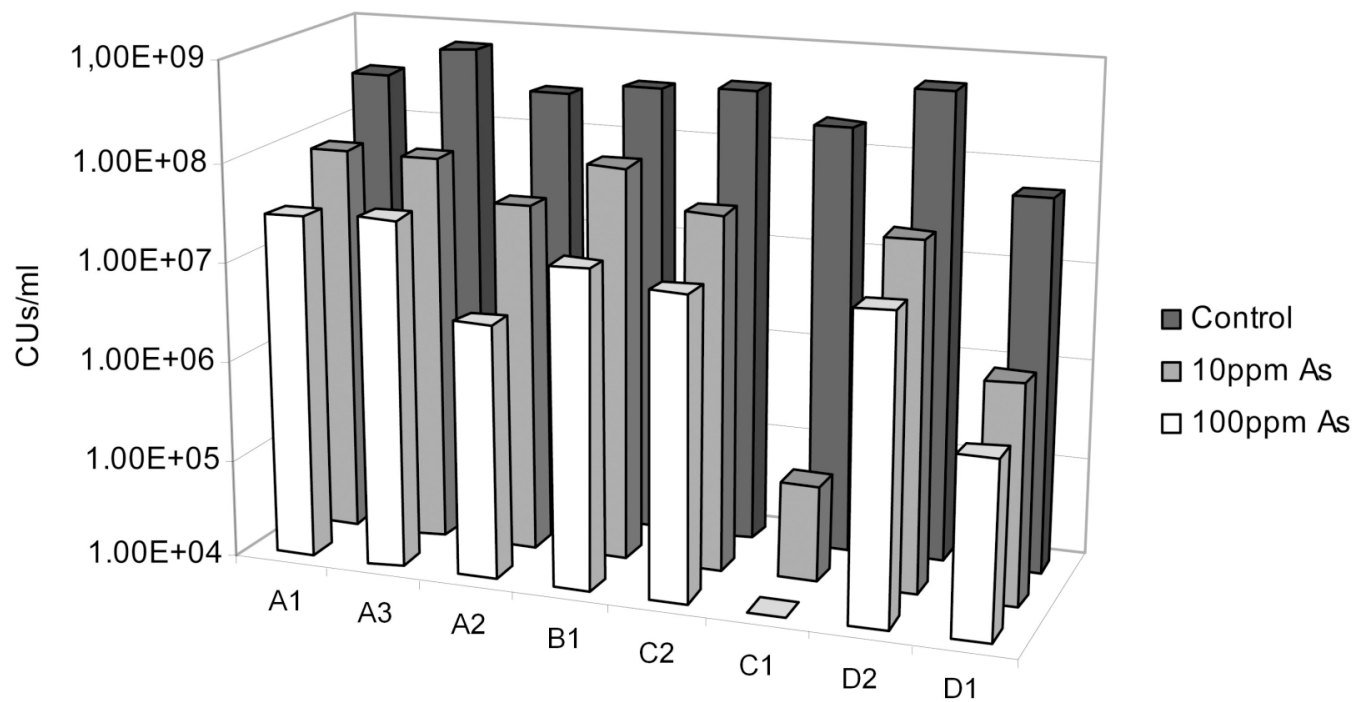

Fig. (7). Decrease of cultivable microbes on PC medium spiked with arsenate.

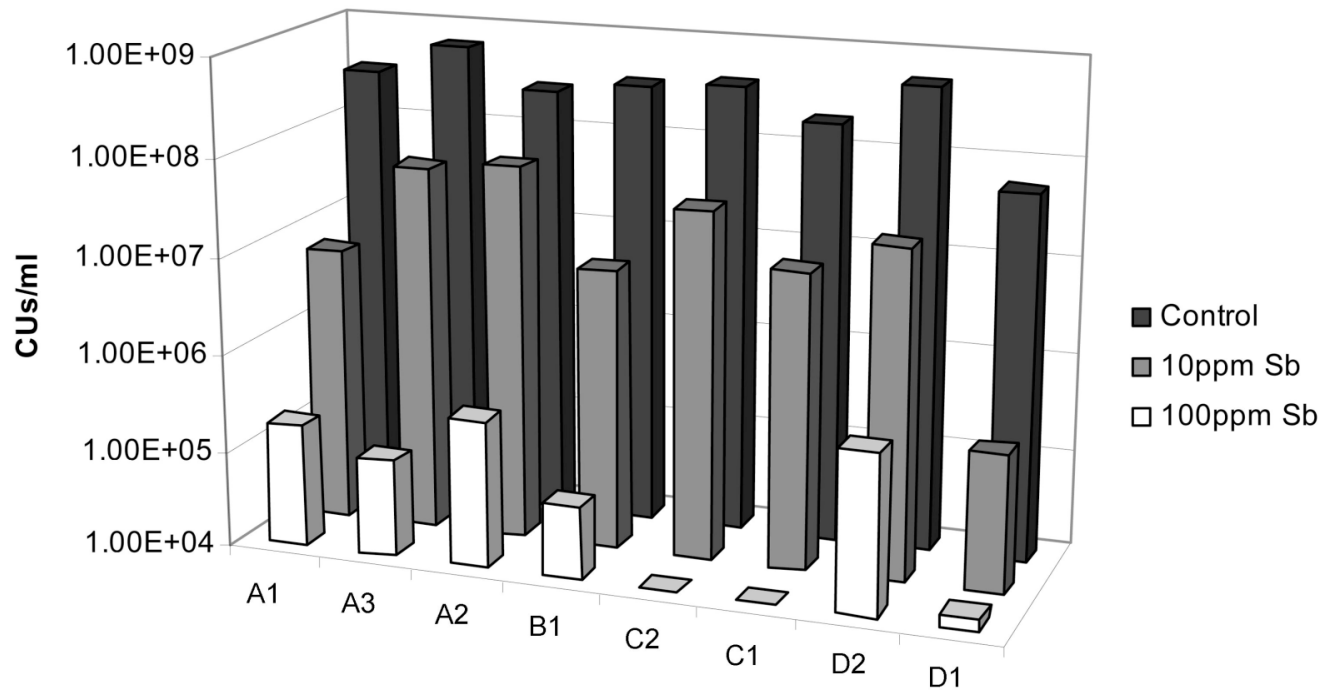

Fig. (8). Decrease of cultivable microbes on PC medium spiked with tartaric emetic. 


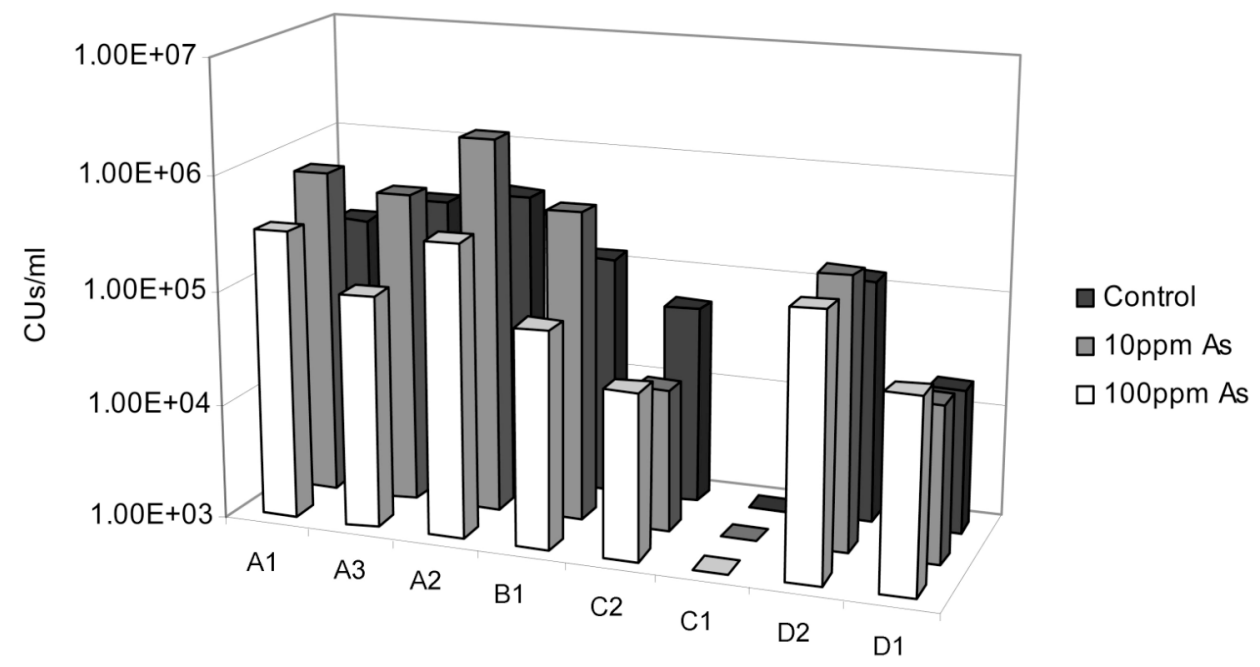

Fig. (9). Increase of cultivable microbes on SOB medium spiked with arsenate.

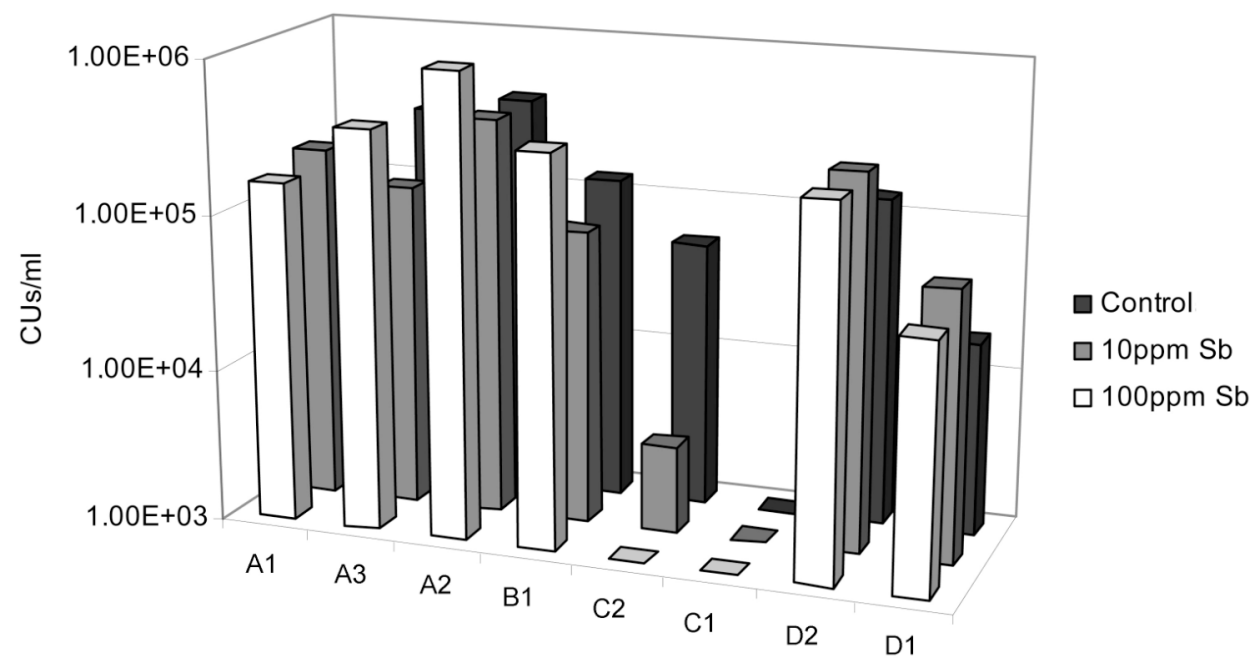

Fig. (10). Inrease of cultivable microbes on SOB medium spiked with tartaric emetic.

\section{DISCUSSION}

In recent years, many studies focused on poisonous metalloids in the environment. The most important example is arsenic-contaminated groundwater in the Bangladesh region that caused widespread diseases. Possible mechanisms of the As release into the aquifer have been discussed in recent papers $[30,31]$. It is appearant that reducing conditions in the fluvial sediments mobilize As. Other studies deal with As and $\mathrm{Sb}$ contamination as a consequence of atmospheric transport or import by herbicides [32-34] or As contamination as a result of metal processing [35]. However, much less is known on habitats with a bedrock rich in metalloids.

This may be due to the comparatively small number of habitats with edaphic metalloids, compared to sites contaminated with heavy metals. In his review of heavy metal habitats in the Eastern Alps, Punz [36] lists 21 habitats contaminated with $\mathrm{Cu}, 48$ with $\mathrm{Cr}$, but only three with $\mathrm{As}$ or $\mathrm{Sb}$, including Schlaining.

\subsection{Soil Chemistry}

Many heavy metal contaminated habitats exhibit rocky and little developed soils or developed soils secondarily degenerated due to heavy metal stress [37]. In such habitats, effects of extreme $\mathrm{pH}$, lacking nutrients, low water holding capacity etc. combine with heavy metal stress to suppress plant growth. This is not the case in the metalloid contaminated habitats in Schlaining. The $\mathrm{pH}$ values were neutral at most sites, in spite of the high abundance of extractable sulphate. The bedrock rich in limestone [4] was and still is able to buffer all sulphuric acid set free by oxidation of sulphides. The same is true for the rivulet D1, containing carbonates in the range of $2.9 \mathrm{mM} \cdot 1^{-1}$. Carbonate buffering of sulphide derived acids on mining sites is well known, in soil [38] as well as in drainage rivulets $[39,40]$, but has experienced little attention so far [41]. In the vast majority of abandoned mining sites, soil and drainage waters are extremely acidic (e. g. [11]). In Schlaining, this was only the case in C1. Here, the buffer capacity of the soil was obviously overstrained by the 
occurrence of sulphuric acid, causing a $\mathrm{pH}$ decrease down to 1.88. After the consumption of lime particles, calcium was precipitated in the form of gypsum. The high concentration in insoluble sulphur - supposingly sulphide - indicates that the process of acidification is far from being finished. To a minor extent, however, soil $\mathrm{pH}$ is influenced by sulphate at all sites: As expected, the sulphate, carbonate and humus content together completely explain $\mathrm{pH}_{\mathrm{H} 2 \mathrm{O}}\left(\mathrm{R}^{2}=0.99 ; \mathrm{P}<\right.$ $0.05)$ and $\mathrm{pH}_{\mathrm{CaCl} 2}\left(\mathrm{R}^{2}=0.99 ; \mathrm{P}<0.01\right)$.

The concentrations of plant nutrients were moderate at all sites. The high abundance of $\mathrm{NH}_{4}{ }^{+}$found at $\mathrm{B} 1$ may indicate disturbed nitrification. The humus content is rather low, compared to typical grassland or woodland habitats and resembles agricultural soils [20]. Three hypotheses may explain the comparatively low effect of high concentrations of toxic metalloids on the soil: (1) In the majority of habitats investigated in this study, the soil is not autochthonous, but was heaped up in recent years during the remediation of the spoil heaps. Long term monitoring will give evidence if metalloid contamination will lead to soil degeneration. (2) In spite of the high concentrations of metalloids, soil microorganisms are still abundant and have partly adapted to metalloid stress (see 4.3). These resistant bacteria and fungi may be able to maintain "normal" soil metabolism. (3) The comparatively low mobility of metalloids (see 4.2) may reduce the toxic effect on soil metabolism.

\subsection{Occurrence and Availability of Metalloids}

Concentrations with toxic metalloids differed strongly between the investitated sites. At A2, no metalloids could be detected, at A1 and C2 the levels were very low. At A3, B1, $\mathrm{C} 1$ and D2, however, metalloids were abundant and exceeded by far the maximal permissible concentrations in soil [42]. At these polluted sites, the concentrations of metalloids were in the same range $\left(370-1410 \mathrm{mg} \cdot \mathrm{kg}^{-1}\right)$ as reported by Armienta et al. [43] for soils next to mine tailings in Mexico (290 - $\left.2580 \mathrm{mg} \cdot \mathrm{kg}^{-1}\right)$. However, mobility of As was much lower $\left(<1.7 \mathrm{mg} \cdot \mathrm{kg}^{-1}\right.$ versus $\left.1.0-8.4 \mathrm{mg} \cdot \mathrm{kg}^{-1}\right)$ compared to mining sites in Mexico [43] and Australia [44]. The mobility rates at Schlaining are rather similar to gossans [44] or historic mining sites $[10,45]$.

In any case, As and $\mathrm{Sb}$ mobility cannot be explained by single parameters. We tested several parameters discussed in earlier studies $[17,46]$ including $\mathrm{pH}$, citrate-dithionite extractable Fe or clay content, but could not find significant correlations. A more complex model published by Jiang et al. [17] including not only extractable Fe and clay but also organic matter content and dissolved organic matter gave only weak and insignificant correlations as well. Unlike Jiang et al. [17], we found a significant correlation between the percentage of mobile As (supposingly $\mathrm{AsO}_{4}{ }^{3-}$ ) and extractable $\mathrm{PO}_{4}{ }^{3-}\left(\mathrm{R}^{2}=0.84 ; \mathrm{P}<0.05\right)$, which probably reflects the competition of these anions for bonding partners (precipitation reactions) [47]. The correlation between mobile As and mobile $\mathrm{Sb}\left(\mathrm{R}^{2}=0.89 ; \mathrm{P}<0.01\right)$ may be due to a similar effect. Mobile As also correlated highly significantly with the total $\mathrm{Sb}$ concentration $\left(\mathrm{R}^{2}=0.96 ; \mathrm{P}<0.01\right)$; however a definite explanation cannot be offered yet.

Besides the similar behaviour of phosphate and arsenate, the mobility of metalloids is difficult to explain. This is probably due to the mineralogical heterogeneity of the sites.
Goldberg [46] provides adsorption data for As(III) and $\mathrm{As}(\mathrm{V})$ on various soil minerals, and describes very different adsorption rates, depending on As species, $\mathrm{pH}$ and respective minerals.

Antimony (and arsenic) ore occurs as intrusions in macroscopic slate or phyllite stones (see Fig. 3). In the fine soil fraction, however, ore particles are rare which is probably due to sulphide oxidation. In X-Ray microanalytical investigations, no ore particles could be found ( $\mathrm{N}=$ approx. 60 ). This may be the consequence of sulphur oxidising bacteria action ([48], see also 4.3) or sulphide dissolution by root exudates [49]. Both factors set soluble As species free.

In spite of the dissolution of sulphides, metalloid mobility was low as shown in Table 2 . The majority of metalloids was adsorbed or embedded in particles of other minerals like aluminosilicate, mica, hornblende etc., according to X-Ray microanalytical investigation. The sorption of As to aluminosilicates is known to be rather loose [50]. The relation between soil mineralogy and metalloid mobility recently became a key issue [16,51,52], but the recent knowledge is too limited for exact predictions for heterogeneous matrices.

In the rivulet D1, a remarkable amount of As was found in the water, and exorbitant As and Sb concentrations were found in the sediment. A similar situation was found by Morillo et al. [53] in the Spanish Odiel river (up to 791 $\mathrm{mg} / \mathrm{kg}$ in the sediment). Compared to drainage waters from As rich spoil heaps in New Zealand [54] (up to $50 \mathrm{mg} / \mathrm{l}$ ), As contamination in the Schlaining rivulet was rather low. At D1, the sediment was formed by goethite-like particles of iron hydroxide that contained up to $0.3 \%$ As. The incorporation of As into iron oxyhydroxyde exhibits a chemical selection, since arsenate is rather preferred than arsenite [55]. Surface water rich in As is a less observed phenomenon than As-calamities like ground- or well-water in Bengal/Bangladesh with As concentrations up to a milligram per litre range, see e.g. [56,57]. However, even rivers and surface waters have been reported to exceed the guideline value of the WHO for As. The As value found in the water of D1 $\left(26 \mu \mathrm{g} \cdot \mathrm{l}^{-1}\right)$ is well above both, the permissible As value in potable water $\left(10 \mu \mathrm{g} \cdot \mathrm{l}^{-1}\right)$ and the global average value of 1.7 $\mu \mathrm{g} \cdot \mathrm{l}^{-1}$ for dissolved As in stream water [58]. In comparison to a study on the water and sediments from the Okavango Delta (Botswana) [59], the As concentration in D1 water was approximately one order of magnitude higher than in surface water from there. Interestingly, the sediments from the Okavango river were relatively poor in As, in the range of $0.2-7 \mathrm{mg} \cdot \mathrm{kg}^{-1}$, compared to the sediments of D1 (4.5\%o As). Several groundwater samples from the Okavango Delta region proved to have much higher As concentrations than the respective surface water samples (up to $177 \mu \mathrm{g} \cdot \mathrm{l}^{-1} \mathrm{As}$ ), suggesting that groundwater from the Schlaining site could have even higher As concentrations, as the sediments are much richer in metalloids there.

Plant availability of $\mathrm{As}$ and $\mathrm{Sb}$ is more difficult to estimate. The Whitney-Man-U-Test gave evidence that extraction with $\mathrm{NH}_{4} \mathrm{NO}_{3}$ (as suggested in [10]) did not yield significantly different metalloid concentrations than pure water extracts. In the literature, some other extraction procedures have been described, including gastric solution (Simplified Bioaccessibility Extraction Test (SBET) for soil) [51], $\mathrm{KCl}$ [60], $\mathrm{Na}_{2} \mathrm{HPO}_{4}$ [47] or EDTA [61], but no standard extrac- 
tion procedure has been developed so far. Further investigations in this direction will be included in the ongoing research in our laboratories.

\subsection{Microorganisms}

Arsenic and antimony have toxic effects on microorganisms in general, but resistant strains evolve readily at contaminated sites [62]. Therefore, the total microbe numbers were weakly, though significantly, reduced at As polluted sites. Antimony had no detectable effect. Only at $\mathrm{Cl}$, where high concentrations of these metalloids were combined with low $\mathrm{pH}$, microbe numbers were strongly diminished.

Concerning cultivable bacteria, the situation was slightly different. Bacteria growing on PC medium proved to be sensitive to enhanced metalloid concentrations, especially to $\mathrm{Sb}$. At the natural habitat, they probable benefit from the spare solubility of metalloids. On media spiked with $100 \mathrm{ppm}$ As, e.g. up to $9 \%$ of the total cultivable bacteria were able to grow, whereas less than $0.1 \%$ were found on a $100 \mathrm{ppm} \mathrm{Sb}$ medium. This result is of specific interest, since the effects of soil $\mathrm{Sb}$ were weaker and less significant. These results may reflect the difficulties to estimate the availability of metalloids for microorganisms.

Different results were found on media for sulphur oxidising bacteria. Though only $10^{4}$ to $10^{5} \mathrm{CUs} / \mathrm{ml}$ (Cultivable Units per $\mathrm{ml}$ ) could be detected, sulphur oxidisers proved to be much more resistant against toxic metalloids. The highest numbers of cultivable units were found not on the unspiked control, but on $10 \mathrm{ppm}$ As. The effect of $100 \mathrm{ppm}$ As was more moderate than on PC medium as well. Concerning $\mathrm{Sb}$ spiking, no general trend could be found. However, a significant decrease of cultivable units was only detected on the virtually uncontaminated site $\mathrm{C} 2$. Since the metalloids occur as sulphidic ores at Schlaining [3], our results indicate that these bacteria are specialised in the utilisation of the noxious ore sulphides. In C1, no cultivable sulphur oxidising bacteria were found; obviously, they are not able to cope with the low $\mathrm{pH}$ of this habitat, though sulphide was available.

Metalloid resistant bacteria were found not only at polluted sites, but also on the uncontaminated habitats A2 and C2. Jackson et al. [63] already described that up to $50 \%$ of the total cultivable bacteria from arsenic free soils may be resistant against arsenate.

Besides the oxidation of sulphide ore particles, other bacteria may affect metalloid mobility by oxidising As(III) to As(V) [64] or vice versa [65], dissolution of pyrite crystals by bacterial ligands [49] or by the precipitation of colloidial ferric arsenate in running water [66]. Due to the lack of anaerobic soils, As release by bacterial Fe reduction [67] can be excluded for Schlaining.

\subsection{Flora of Contaminated Microhabitats}

In Site A, the slightly inclined, west exposed meadow was superficially very uniform. Soil composition, on the other hand, differed largely between the three sampled microhabitats. These differences, however, were not reflected by the floristic composition. Only little effects of $\mathrm{As}$ and $\mathrm{Sb}$ contamination in A3 were found. Several species, e. g. Arrhenaterum elatius, Aster lanceolata, Festuca pratensis or Solidago canadensis were found all over the meadow. The number of species was largest in the heavy contaminated A3 and smallest in A2 without detectable As and Sb. However, open patches were only found at A3. This was also the only part of the whole meadow where three species of mosses were able to grow between the vascular plants. Virtually all species, vascular plants as well as mosses, were typical for more or less nutrient rich meadows. With the exception of Silene vulgaris [68] and Thlaspi sp. (e. g. [69]), no species or genera typical for habitats contaminated with heavy metals could be detected. A more or less limited resistance to heavy metals was also described for Festuca, Viola, Rumex and Lotus [70], which were all found in the Schlaining mining site as well. Holcus was described to be As resistant [71], but occurred in Schlaining only at the uncontaminated microsite A2.

At the heavily contaminated site B1, meadow and forest species were intermixed. The number of species and the coverage were low. However, no typical metallophytes were found.

At Site C, conditions were far from being natural, since Picea abies forests do not naturally occur in Burgenland. Accordingly, only deciduous trees and shrubs were found in the understorey. Due to the low level of contamination, depletion of the flora was neither expected nor found at $\mathrm{C} 2$. $\mathrm{C} 1$, however, proved to be the most extreme habitat found at Schlaining. Here, neither vascular plants nor mosses were found. The only organisms were bacteria forming an orange biofilm at the surface of the mud.

D2, the meadow at rivulet D1, exhibited a very low biodiversity. Only six species of embryophytes could be detected. It is tempting to ascribe this to the very high amounts of total and mobile As and $\mathrm{Sb}$ (3.6\%!). However, shadowing by neighbouring trees or destructive flooding by the nearby creek may contribute to lower biodiversity as well. Accordingly, shading resistant genera like Viola, Hedera, Plagiomnium or Oxalis were dominant. No floristic overlapping with other sites - contaminated or not - was found.

Rivulet D1 was even poorer in species than the neighbouring meadow D2, though, except for metalloids, no other extreme parameters were found. Thus it is highly probable that the $\mathrm{As}$ (and $\mathrm{Sb}$ ) content is responsible for the lack of species. The flora was dominated by bacteria only (e.g. as shown in Fig. 6).

As a summary, no evidence for the formation of a specific As-Sb-flora could be found, as it is well known for heavy metal contaminated habitats [72]. Even very high amounts of total and mobile $\mathrm{As}$ and $\mathrm{Sb}$ are tolerated by a closed though species poor vegetation (D2). Besides metalloid contamination, soil conditions were favourable at most investigated sites. A significant decrease in species numbers was found to be exclusively a function of the total As content.

Thus, our results support the hypothesis of Craw et al. [54] that colonisation of As rich habitats is often limited rather by the lack of nutrients than by the occurrence of toxic metalloids. In Schlaining, bold patches are only formed if high concentrations of As and $\mathrm{Sb}$ occur in combination with low $\mathrm{pH}(\mathrm{C} 1)$ or intense shadowing $(\mathrm{C} 1, \mathrm{D} 2)$; the influence of acidic soils is significant. More subtle effects of $\mathrm{As}$ and $\mathrm{Sb}$ stress on the vegetations are probable, but will be difficult to 
detect, since many other soil parameters vary between the sampled sites at the Schlaining mining site.

\section{CONCLUSIONS AND FUTURE ASPECTS}

This multidisciplinary study of the former mining site in Schlaining allows the following insights:

- In spite of extensive measures for renaturation, considerable amounts of the metalloids $\mathrm{As}$ and $\mathrm{Sb}$ (in the range of weight $\%$ ) are found at several microsites in the former mining area. In most of the area, however, the metalloid content of the soil is negligible. Though the mobility of metalloids is relatively low, constant leaching of metalloids occurs through at least one rivulet and most probably into the ground water.

- $\quad$ The metalloids investigated in this study are derived from Sb-bearing sulphidic ore minerals. Though the mine waste is derived from only one orebody, the petrological composition of the bedrock differs between the microsites. Also, the ratios between As and $\mathrm{Sb}$ are only weakly correlated. This may be due to a different geochemical differentiation during the formation of the orebody.

- $\quad$ Consequently, soil properties differ significantly between various microsites. Differences include $\mathrm{pH}$, nutrient and carbonate content and mineralogical composition. With the exception of metalloid contamination, soil parameters are moderate in most cases. Arsenic (supposedly in the form of $\mathrm{AsO}_{4}{ }^{3-}$ ) and $\mathrm{PO}_{4}{ }^{3-}$ mobility were correlated, reflecting the chemical similarity of these anions.

- $\quad$ Plant biodiversity is significantly affected by As, but not by Sb contamination. At the most polluted sites, a drastic decrease in species or bold patches were observed. However, no specific, metalloid resistant plant communities seem to exist at Schlaining. Our results support the hypothesis that floristic effects of metalloid contamination are significantly tempered by the presence of a thick soil layer rich in nutrients, carbonate and humus. In contrast to this, the aquatic environment of a small rivulet (D1) in the vicinity of the overburden deposits seems to be affected by the metalloid concentrations. The permissible values for As in drinking water were increased by a factor of 2.6. The fact that the biodiversity in the rivulet was obviously impacted cannot be due to other hydrological parameters, which were, as far as we know, all in the normal range. Thus it is very likely that the metalloid content caused these adverse effects to the aquatic biosystem.

- The recent and established models to predict metalloid mobility are also insufficient for habitats with a heterogeneous mineralogical background.

The number of soil bacteria is not affected by metalloid contamination. At all sites, at least some strains were resistant to $100 \mathrm{ppm}$ As and Sb. Organotrophic bacteria cultivated on PC medium proved to be more sensitive than sulphur oxidising strains. The latter even seem to benefit from moderate As spiking and are possibly adapted to the degradation of sulphidic metalloid ores.
Due to its profound geological and mineralogical characterisation and the diversity of contaminated habitats, the mining site of Schlaining can be used as a model ecosystem to study the availability and mobility of metalloids. Future studies will include speciation of As using SynchrotronRadiation-Induced Total Reflection X-Ray Analysis [73]. Furthermore, microbial biodiversity will be characterised using molecular techniques; special attention will be laid on microbial transformations of As and Sb [64,74]. Futhermore, native species from Schlaining may be suitable for phytoremediation of other metalloid contaminated sites [75].

Possible endangerment of man and environment deserves specific investigation. Arsenic contamination of the soil surface is always regarded as dangerous, due to the possibility of incidental ingestion from hand-to-mouth activity, especially for children [44]. Though toxic metalloids basically may endanger humans via the food-chain [76], this can be excluded for Schlaining, since no food plants are grown at the contaminated sites. A nearby pasture proved to be uncontaminated. However, water of rivulet D1 enters the river Tauchenbach, passing through the city of Stadtschlaining. Long range transport and precipitation of As will be influenced by the incorporation into Fe oxyhydroxides with very different mobility [66,77] or by polymerisation [78], both depending on metalloid speciation and bacterial activity. Thus, it is yet impossible to make any prediction of As and $\mathrm{Sb}$ contamination in settled areas which should be investigated in the next future.

\section{ACKNOWLEDGEMENTS}

We are indebted to Dr. Josef Hofer for his generous and valuable help in the course of sampling by explaining the geological setting of the mining site. Furthermore we thank Michaela Foster for help in the sample preparation.

This study was supported by the Austrian Science Foundation WWTF, project L433-B17.

\section{REFERENCES}

[1] Shotyk W, Krachler M, Chen B. Antimony: global environmental contaminant. J Environ Monit 2005; 7: 1135-6.

[2] Halisch P, Hübler und Grübler, Goberling - eine burgenländische Gemeinde zwischen Landwirtschaft und Bergbau, Austria: Universität Wien 1983.

[3] Pollak A. Neuere untersuchungen auf der antimonerzlagerstätte schlaining. Berg Hüttenmänn Monatsh 1955; 100: 137-45.

[4] Lukas W. Zur genese der antimonitlagerstätte schlaining (Burgenland). Tschermaks Miner u Petrogr Mitt 1970; 14: 87-101.

[5] Cerny I. Geochemische untersuchung von karbonatgesteinen im antimonbergbau schlaining (Burgenland). Berg Hüttenmänn Monatsh 1981; 126: 524-27.

[6] Grum W, Frimmel HE, Koller F. Sr-Isotopendaten zur genese der antimonit-lagerstätte schlaining (Burgenland, Österreich). Mitteilungen der Österreichischen Mineralogischen Gesellschaft 1992; 137: 144 .

[7] J. Hofer. Personal communication.

[8] WHO: Health topics: water; http://www.searo.who.int/EN/Section 314_4295.htm, 2004. [September 2008].

[9] Boyle RW, Jonason IR. The geochemistry of antimony and its use as an indicator element in geochemical prospecting. J Geochem Explor 1984; 20: 223-302.

[10] Hammel W, Debus R, Steubing I. Mobility of antimony in soil and its availability to plants. Chemosphere 2000; 41: 1791-8.

[11] Lång L-O. Heavy mineral weathering under acidic soil conditions. Appl Geochem 2000; 15: 415-23.

[12] Öhlinger R. Bestimmung von Phosphor in Bodenextrakten; In: Schinner F, Öhlinger R, Kandeler E, Margesin R, Eds. Bodenbio- 
logische Arbeitsmethoden. Berlin: Springer Verlag, 1993; pp. 3713.

[13] Öhlinger R. Bestimmung des Biomasse-Phosphors mittels Fumigation-Extraktion; In: Schinner F, Öhlinger R, Kandeler E, Margesin R, Eds. Bodenbiologische Arbeitsmethoden, Berlin: Springer Verlag 1993; pp. 66-8.

[14] Kandeler E. Bestimmung von Ammonium; In: Schinner F, Öhlinger R, Kandeler E, Margesin R, Eds. Bodenbiologische Arbeitsmethoden, Springer Verlag, Berlin 1993; pp. 366-8.

[15] Kandeler E. Bestimmung von Nitrat; In: Schinner F, Öhlinger R, Kandeler E, Margesin R, Eds. Bodenbiologische Arbeitsmethoden, Springer Verlag, Berlin 1993; pp. 369-71.

[16] Manning B, Suarez DL. Modeling Arsenic(III) adsorption and heterogeneous oxidation kinetics in soil. Soil Sci Soc Am J 2000; 64: $128-37$.

[17] Jiang W, Zhang S, Shan X-q, Feng M, Zhu Y-G, McLaren RG. Adsorption of arsenate on soils. Part 2: Modeling the relationship between adsorption capacity and soil physiochemical properties using 16 Chinese soils. Environ Pollut 2005; 38: 285-9.

[18] Öhlinger R. Bestimmung der Korngrößenverteilung; In: Schinner F, Öhlinger R, Kandeler E, Margesin R, Eds. Bodenbiologische Arbeitsmethoden. Berlin: Springer Verlag 1993; pp. 347-50.

[19] Insam H. In: Schinner F, Öhlinger R, Kandeler E, Margesin R, Eds. Bestimmung des organischen Kohlenstoffs $\left(\mathrm{C}_{\text {org }}\right)$ mittels trockener Verbrennung; Bodenbiologische Arbeitsmethoden, Berlin: Springer Verlag 1993; pp. 360-2.

[20] Kandeler E. In: Schinner F, Öhlinger R, Kandeler E, Margesin R, Eds. Humusbestimmung durch Naßoxidation; Bodenbiologische Arbeitsmethoden, Berlin: Springer Verlag 1993; pp. 356-7.

[21] Oehme F, Schuler P. Gelöst-Sauerstoff-Messung, Heidelberg: A. Hüthig-Verlag 1983.

[22] Trolldenier G. In: Schinner F, Öhlinger R, Kandeler E, Margesin R, Eds. Fluoreszenzmikroskopische Zählung von Bodenbakterien; Bodenbiologische Arbeitsmethoden, Berlin: Springer Verlag, 1993; pp. 16-21.

[23] Kimmig J, Rieth H. Antimykotika in experiment und klinik. Arzneimittelforschung 1959; 3: 267-76.

[24] Hines ME, Visscher PT, Devereux R. Sulfur Cycling. In: Crawford RL, Knudsen GR, McInerney MJ, Stetzenbach LD, Eds. Manual of environmental microbiology, Washington D.C.: ASM Press 2002; pp. 427-38.

[25] Papageorgiou B. Untersuchung zur phytosantiären Wirksamkeit und zu Wirkmechanismen wässriger Extrakte aus westafrikanischen Bioabfallkomposten gegen pilzliche Pathogene. Germany: Humbold-Universität Berlin 2003.

[26] Steinnes E. Neutron activation analysis in the geosciences: Lost territory, or new deal? J Radioanal Nucl Chem 2004; 261: 701-8.

[27] Steinhauser G, Sterba JH, Bichler M, Huber H. Neutron activation analysis of Mediterranean volcanic rocks - An analytical database for archaeological stratigraphy. Appl Geochem 2006; 21: 1362-75.

[28] Scheffer F, Schachtschnabl P, Blume HP, et al. Lehrbuch der Bodenkunde, $15^{\text {th }}$ ed. Spektrum Akademischer Verlag: Heidelberg 2002.

[29] Violante A, Del Gaudio S, Pigna M, Ricciardella M, Banerjee D. Coprecipitation of arsenate with metal oxides. 2. nature, mineralogy, and reactivity of iron(III) precipitates. Environ Sci Technol 2007; 41: 8275-80.

[30] Quicksall AN, Bostick BC, Sampson ML. Linking organic matter deposition and iron mineral transformations to groundwater arsenic levels in the Mekong delta, Cambodia. Appl Geochem 2008; 23: 3088-98.

[31] Larsen F, Pham NQ, Dang ND, et al. Controlling geological and hydrogeological processes in an arsenic contaminated aquifer on the Red River flood plain, Vietnam. Appl Geochem 2008; 23: 3099-115.

[32] Steinnes E, Hvatum OO, Bølviken B, Varskog P. Atmospheric polltutants and trace gases. J Environ Qual 2005; 34: 192-7.

[33] Fetter CW. Contaminant hydrogeology, Prentice Hall: Upper Saddle River 1999.

[34] Smichowski P. Antimony in the environment as a global pollutant: A review on analytical methodologies for its determination in atmospheric aerosols. Talanta 2008; 75: 2-14.

[35] Lin YP. Simulating spatial distributions, variability and uncertainty of soil arsenic by geostatistical simulations in geographic information systems. Open Environ Sci 2008; 2: 26-33.
[36] Punz W. Kartierung von schwermetallbiotopen im ostalpenraum. Sauteria 1999; 10: 61-76.

[37] Banasova V, Horak O, Ciamporova M, Nadubinska $M$, Lichtscheidl I. The vegetation of metalliferous and nonmetalliferous grasslands in two former mine regions in Central Slovakia. Biologia 2006; 61: 433-9.

[38] Strömberg B, Banwart S. Experimental study of acidity-consuming processes in mining waste rock: some influences of mineralogy and particle size. Appl Geochem 1999; 14: 1-16.

[39] Cravotta CA, Trahan MK. Limestone drains to increase $\mathrm{pH}$ and remove dissolved metals from acidic main drainage. Appl Geochem 1999; 14: 581-606.

[40] Hammarstrom JM, Sibrell PL, Belkin HE. Characterization of limestone reacted with acid-mine drainage in a pulsed limestone bed treatment system at the Friendship Hill National Historical Site, Pennsylvania, USA. Appl Geochem 2003; 18: 1705 - 21.

[41] Zeggel L, Zellmer A, Pieplow G, Kothe E. Microbe assisted phytoextraction on contaminated concrete: $7^{\text {th }}$ Symposium on remediation in Jena "Jenaer Sanierungskolloquium": Metall stress: Biotic and abiotic factors. Germany: Jena 2008; p. 26.

[42] He MC. Distribution and phytoavailability of antimony at an antimony mining and smelting area, Hunan, China. Environ Geochem Health 2007; 29: 209-19.

[43] Armienta MA, Ongley LK, Rodríguez R, Cruz O, Mango H, Villaseñor G. Arsenic distribution in mesquite (Prosopis laevigata) and huizache (Acacia farnesiana) in the Zimapán mining area, Mexico. Geochem Explor Environ Anal 2008; 8: 191-7.

[44] Smith E, Naidu R, Weber J, Juhasz AL. The impact of sequestration on the bioaccessibility of arsenic in long-term contaminated soils. Chemosphere 2008; 71: 773-80.

[45] Casado M, Anawar HM, Garcia-Sanchez A, Regina IS. Antimony and arsenic uptake by plants in an abandoned mining area. Commun Soil Sci Plant Anal 2007; 38: 1255-75.

[46] Goldberg S. Competitive adsorption of arsenate and arsenite on oxides and clay minerals. Soil Sci Soc Am J 2002; 66: 413-21.

[47] Nakamaru YM, Sekine K. Sorption behaviour of selenium and antimony in soils as a function of phosphate ion concentration. Soil Sci Plant Nutr 2008; 54: 332-41.

[48] Monroy-Fernandez MG, Mustin C, de Donato P, Barres O, Marion $\mathrm{P}$, Berthelin J. Occurences at mineral-bacteria interface during oxidation of arsenopyrite by Thiobacillus ferrooxidans. Biotechnol Bioeng 2005; 46: 13-21.

[49] Cornejo-Garrido H, Fernandez-Lomelin P, Guzman J, CerviniSilva J. Dissolution of arsenopyrite (FeAsS) and galena $(\mathrm{PbS})$ in the presence of desferrioxamine-B at $\mathrm{pH}$ 5. Geochim Cosmochim Acta 2008; 72: 2754-66.

[50] Foster AL. Spectroscopic investigations of arsenic species in solid phases. In: Welch AH, Stollenwerk KG, Eds. Arsenic in groundwater, New York: Springer 2002; pp. 27-66.

[51] Juhasz AL, Smith E, Weber J, et al. Effect of soil ageing on in vivo on arsenic bioavailability in two dissimilar soils. Chemosphere 2008; 71: 2180-6.

[52] Paktunc D, Dutrizac J, Gertsman V. Synthesis and phase transformations involving scorodite, ferric arsenate and arsenical ferrhydrite: Implications for arsenic mobility. Geochim Cosmochim Acta 2008; 72: 2649-72.

[53] Morillo J, Usero J, Rojas R. Fractionation of metals and As in sediments from a biosphere reserve (Odiel salt marshes) affected by acidic mine drainage. Environ Monit Assess 2008; 139: 329-37.

[54] Craw D, Rufaut C, Haffert L, Paterson L. Plant colonization and arsenic uptake on high arsenic mine wastes, New Zealand. Water Air Soil Pollut 2007; 179: 351 - 64.

[55] Dreyer JI. The Geochemistry of Natural Waters. Surface and Groundwater Environments, $3^{\text {rd }}$ ed, Prentice Hall: Upper Saddle River 1997.

[56] Chaterjee A, Das D, Mandal BK, Chowdhury TR, Samanta G, Chakraborti D. Arsenic in ground water in six districts of west Bengal, India: the biggest arsenic calamity in the world. Part I. Arsenic species in drinking water and urine of the affected people. Analyst 1995; 120: 643-50.

[57] Da D, Chatterjee A, Mandal BK, Samanta G, Chakraborti D, Chanda B. Arsenic in ground water in six districts of West Bengal, India: the biggest arsenic calamity in the world. Part 2. Arsenic concentration in drinking water, hair, nails, urine, skin-scale and liver tissue (biopsy) of the affected people. Analyst 1995; 120: $917-$ 24. 
[58] Martin JM, Whitfield M. The significance of the river input of chemical elements into the ocean; In: Wong CS, Boyle E, Bruland KW, Burtons JD, Goldberg ED, Eds. Trace Metals in Sea Water, New York: Plenum 1983; pp. 65-296.

[59] Huntsman-Mapila P, Mapila T, Letshwenyo M, Wolski P, Hemond C. Characterization of arsenic occurrence in the water and sediments of the Okavango Delta, NW Botswana. Appl Geochem 2006; $21: 1376-91$.

[60] Lin HT, Wang MC, Seshaiah K. Mobility of absorbed arsenic in two calcareous soils as influenced by water extract of compost. Chemosphere 2008; 71: 742-9.

[61] De Gregori I, Fuentes E, Olivares D, Pinochet H. Extractable copper, arsenic and antimony by EDTA solution from agricultural Chilean soils and its transfer to alfalfa plants. J Environ Monit 2004; 6: 38-47.

[62] Hoostal MJ, Bidart-Bouzat MG, Bouzat JL. Local adaptation of microbial communities to heavy metal stress in polluted sediments of Lake Erie. FEMS Microbiol Ecol 2008; 65: 156-68.

[63] Jackson CR, Dugas SL, Harrison KG. Enumeration and characterization of arsenate-resistant bacteria in arsenic free soils. Soil Biol Biochem 2005; 37: 2319-22.

[64] Rhine ED, Onesios KM, Serfes ME, Reinfelder JR, Young LY. Arsenic transformation and mobilization from minerals by the arsenite oxidizing strain WAO. Environ Sci Technol 2008; 42: 14239.

[65] Rathinasabapathi B, Raman SB, Kertulis G, Ma L. Arsenicresistant proteobacterium from the phyllosphere of arsenichyperaccumulating fern (Pteris vittata L.) reduces arsenate to arsenite. Can J Microbiol 2006; 52: 695-700.

[66] Leblanc M, Achard B, Ben Othman D, Luck JM, Bertrand-Sarfati $\mathrm{J}$, Personné JC. Accumulation of arsenic from acidic mine waters by bacterial accretions (stromatolites). Appl Geochem 1996; 11: 541-54.

[67] Radloff KA, Manning AR, Mailloux B, et al. Considerations for conducting incubations to study the mechanisms of As release in reducing groundwater aquifers. Appl Geochem 2008; 23: 3224-35.

[68] Bringezu K, Lichtenberger O, Leopold I, Neumann D. Heavy metal tolerance of Silene vulgaris. J Plant Physiol 1999; 154: 536-46.
[69] Koch M, Mummenhoff K, Hurka H. Systematics and evolutionary history of heavy metal tolerant Thlaspi caerulescens in Western Europe: evidence from genetic studies based on isozyme analysis. Biochem Syst Ecol 1998; 26: 823-38.

[70] Punz WF. Metallophytes in the Eastern Alps with special emphasis on higher plants growing on Calamine and copper localities. Phyton $1995 ; 35: 295-309$.

[71] Macnair MR, Cumbes Q. Evidence that arsenic tolerance in Holcus lanatus L. is caused by an altered phosphate uptake system. N Phytol 1987; 107: 387-94.

[72] Punz W, Mucina L. Vegetation on anthropogenic metalliferous soils in the Eastern Alps. Folia Geobot 1997; 32: 283-95.

[73] Meirer F, Pepponi G, Streli C, et al. Application of synchrotronradiation-induced TXRF-XANES for arsenic speciation in cucumber (Cucumis sativus L.) xylem sap. X-Ray Spectrum 2007; 36: 408-12.

[74] Bentley R, Chasteen TG. Microbial methylation of metalloids: Arsenic, antimony, and bismuth. Microbiol Mol Biol Rev 2002; 66: 250-71.

[75] Neagoe A, Onete M, Pauca M, Iordache V. Native vegetation in mining areas as a source of contaminated hot spots remediation: $7^{\text {th }}$ Symposium on remediation in Jena "Jenaer Sanierungskolloquium": Metall stress: Biotic and abiotic factors. Germany: Jena 2008; p. 24.

[76] Mondal D, Polya DA. Rice is a major exposure route for arsenic in Chakdaha block, Nadia district, West Bengal, India: A probabilistic risk assessment. Appl Geochem 2008; 23: 2987-98.

[77] Fritzsche A, Totsche KU. Changes in arsenic mobility as a result of stability changes of iron colloids after leaching from soil: $7^{\text {th }}$ Symposium on remediation in Jena "Jenaer Sanierungskolloquium": Metall stress: Biotic and abiotic factors. Germany: Jena 2008; p. 16.

[78] Nordstrom DK, Archer DG. Arsenic thermodynamic data and environmental geochemistry; In: Welch AH, Stollenwerk KG, Eds. Arsenic in groundwater, New York: Springer 2002; pp. 1-26.

[79] National Nuclear Data Center; http://www.nndc.bnl.gov/, 2008

[80] BEV: Österreichische Karte 1:50 000: 5219 Oberwart. Wien: Bundesamt für Eich- und Vermessungswesen 2007.

(C) Steinhauser et al.; Licensee Bentham Open.

This is an open access article licensed under the terms of the Creative Commons Attribution Non-Commercial License (http://creativecommons.org/licenses/by$\mathrm{nc} / 3.0 /$ ) which permits unrestricted, non-commercial use, distribution and reproduction in any medium, provided the work is properly cited. 